\title{
Is the Medical Brain Drain Beneficial? \\ Evidence from Overseas Doctors in the UK
}

\author{
Mari Kangasniemi, L. Alan Winters \\ and Simon Commander
}

February 2004 


\begin{abstract}
The 'beneficial brain drain' hypothesis suggests that skilled migration can be good for a sending country because the incentives it creates for training increase that country's supply of skilled labour. To work, this hypothesis requires that the degree of screening of migrants by the host country is limited and that the possibility of migration actually encourages home country residents to obtain education. We studied the implications of doctors' migration by conducting a survey among overseas doctors in the UK. The results suggest that the overseas doctors who come to the UK are carefully screened and that only a minority of doctors from developing countries considered the possibility of migration when they chose to obtain medical education. The incentive effect is thus probably not large enough to increase the skills-supply in developing countries. Doctors do, however, remit income to their home countries and many intend to return after completing their training in the UK, so there could be benefits via these routes.
\end{abstract}

JEL classification: F22, J44, J61

Keywords: brain drain, international labour market, professional labour markets, doctors, physicians, international migration.

This paper was produced as part of the Centre's Labour Markets programme. The Centre for Economic Performance is financed by the Economic and Social Research Council.

\title{
Acknowledgements
}

This research was funded by the Department of International Development (UK). We are also grateful to Janet Grant and her colleagues in the Open University for help with the data used in the paper, and to participants in seminars at the Department for International Development, London (January 2003) and in New Delhi and Brussels organised by the EU-India Network on Trade and Development (May 2003), and Prof. Robert Rowthorn for comments on earlier drafts.

Mari Kangasniemi is currently a research officer at the Center for Economic Performance, formerly a research officer in Poverty Research Unit at the University of Sussex, where this research was conducted. L Alan Winters is a senior research associate at the Centre for Economic Performance, research fellow at the Centre for Economic Policy Research, and professor of economics at the University of Sussex. Simon Commander is a director at the Centre for New and Emerging Markets, London Business School and senior advisor in European Bank of Reconstruction and Development.

Contact details: Mari Kangasniemi, Centre for Economic Performance, London School of economics, Houghton Street, London WC2A 2AE, M.H.Kangasniemi@lse.ac.uk; L Alan Winters, Faculty of Social Sciences, University of Sussex, Falmer, Brighton BN1 9SN, 1.a.winters@sussex.ac.uk; Simon Commander, Centre for New and Emerging Markets, London Business School, Regents Park, London NW1 4SA, scommander@london.edu .

Published by

Centre for Economic Performance

London School of Economics and Political Science

Houghton Street

London WC2A 2AE

All rights reserved. No part of this publication may be reproduced, stored in a retrieval system or transmitted in any form or by any means without the prior permis sion in writing of the publisher nor be issued to the public or circulated in any form other than that in which it is published.

Requests for permission to reproduce any article or part of the Working Paper should be sent to the editor at the above address.

(C) M. Kangasniemi, L. A. Winters and S. Commander, submitted 2003

ISBN 0753017202 


\section{Introduction}

The brain drain has been a prominent concern in many developing countries since the 1960s. The migration of doctors in particular has received considerable attention ${ }^{1}$. To date, however, discussion among economists has generally been more reliant on theory and anecdote than on formal data analysis. Empirical research concerning medical migration, or even on the brain drain from sending country's point of view in general, has been scarce ${ }^{2}$.

It is often assumed in public discussion that brain drain is an unambiguously negative phenomenon. Theory, however, has suggested that it can be beneficial, e.g. if migrants establish commercial networks abroad, remit significant amounts of income or technology, or return with greater skills, or if the possibility of migration increases the incentives to obtain education (Mountford, 1997). Despite the prominence of the last in theoretical discussion, under the heading of "beneficial brain drain" there have been few tests of its relevance or size. Beine, Docquier and Rapoport (2002) study the beneficial brain drain at the economy wide level, but we know of no studies regarding the possibility of beneficial brain drain on specific sectors. Since the choice of education is unlikely to concern only the length and level of general education but also its nature and the future professions it supports, such a sectoral view can yield important insights. This paper aims to fill some of this gap, or at least to serve as a stepping stone for future research through and empirical study of medical migration into the UK.

The UK's National Health Service (NHS) has always employed overseas doctors, especially those from Indian subcontinent. In the mid-1980s, however, it was still believed that the United Kingdom would face an excess supply of doctors by the end of the millennium, and that the intake of British medical schools should be cut down. In the late 1980s and 1990s, however, NHS reforms, demographic change and various other factors caused the demand for doctors to increase substantially, and an increasing number of overseas doctors was needed to fill the gaps (Rivett 1997). Most of these doctors come to the UK to fill basic specialist training posts, many with the intention of pursuing higher specialist training later. Basic specialist training posts provide training, but are held by fully qualified doctors and are key to the delivery of health care in the NHS. Indeed, the system is now heavily dependent on overseas recruits. Until now it has not been clear how large a fraction

\footnotetext{
1 See, for example, Beecham 2002, Bundred and Levitt 2000.

${ }^{2}$ Some of the few examples of the former are an article by Goldfarb et. al (1984) who examine the outflow of Philippine physicians and remittances sent by them and Findlay et al's (1994) analysis of the length of Hong Kong doctors' employment abroad.
} 
of overseas doctors intend to stay in the UK after their training, nor how many actually end up staying. However, it is clear that there is scope for a major brain drain from developing countries via this route.

The present study is based on a small telephone (and in a few cases postal) survey of overseas doctors working in the United Kingdom. This approach has obvious weaknesses for example, that we are not able to compare the migrant doctors with their peers who did not move and that the data are necessarily based on subjective statements given by the migrant doctors themselves - but we believe that it is sufficiently useful to shed at least some new light on what is a major policy issue.

Our principal aim is to establish some facts regarding the influence that migration possibilities have on the educational decisions of individual doctors, and to explore the extent to which migrant doctors to the UK are screened for ability. These are the two fundamental links in the beneficial brain drain hypothesis, and although our sample is small and subject to limitations, this will constitute, to our knowledge, the first attempt to study the relevance of the hypothesis at sectoral level. In addition to the main issues we also enquired about other issues that might influence the total cost or benefit of migration, such as return intentions, remittances and which sector they intend to work in after their return.

The structure of this paper is the following. In section II we summarise the main theoretical considerations concerning the brain drain. In section III we describe the UK National Health System and the ways in which overseas doctors enter the system. In section IV we describe our data set. Section V presents the results of the survey and tests some simple hypotheses concerning screening of applicants and section VI concludes.

\section{Theoretical background ${ }^{3}$}

Some of the earliest work on the brain drain - particularly Grubel and Scott (1966) - was set in the context of perfectly competitive markets. With all markets clearing, wages set equal to marginal product and no externalities, there was evidently no welfare impact on those left behind. ${ }^{4}$ Subsequent research overturned this by introducing distortions between the social and private marginal product and/or a public subsidy for education. Bhagwati and Hamada

\footnotetext{
${ }^{3}$ Commander, Kangasniemi and Winters (2002) provide a fuller account of the literature.

${ }^{4}$ Johnson (1967), however, points out that the effect actually depends on how much capital the emigrants take with them. If capital is internationally mobile this argument does not hold.
} 
(1974), for example, introduced institutional constraints on wage setting and the financing of education, while Bhagwati and Hamada (1975) introduced further 'refinements' to labour markets in the sending countries, such as emigration allowing, in particular circumstances, better matching of skilled workers to jobs. A number of dynamic models - particularly Rodriguez (1975) - had similar points of departure including, inter alia, a Harris-Todaro labour market and sticky wages.

More recent models of the brain drain have introduced the possibility of a beneficial brain drain through education incentives. The central proposition is that if the possibility of emigration encourages more skill-creation than skill-loss, sending (or home) countries might increase their stocks of skills as opportunities to move or work abroad open up. If, in addition, this accumulation of skills has beneficial effects beyond the strictly private gains anticipated by those who acquire the skills, the whole economy can benefit. Examples of such benefits include enhanced intergenerational transmission of skills and education (Vidal, 1998) and spillovers between skilled workers (Mountford, 1997).

There are two critical features of these models. The first is the nature of the social benefit resulting from higher skills, for which several approaches are evident. In the simplest form Stark, Helmenstein and Prskawetz (1997, 1998) merely assume that increasing the average skill level of the sending economy is desirable. Mountford (1997) postulates a production externality whereby the productivity of current labour depends positively on the share of the population who had education in the previous period. Beine, Docquier and Rapaport (2001a) formalise this by allowing the average skill of one generation to pass directly to the next, who can then build on it by taking education. In all these cases, emigration has a negative direct effect by draining skilled labour out of the sending economy - a 'drain' effect - but a potentially beneficial effect by encouraging human capital formation - a 'brain' effect.

The second critical issue for the beneficial brain drain is the mechanism that generates an increased incentive to acquire education but leaves some skilled workers back at home. All the current literature starts with wages for given levels of skills/ ability being higher abroad than at home. From there, the predominant approach - Mountford (1997), Stark, Helmenstein and Prskawetz (1998), Vidal (1998) and Beine, Docquier and Rapaport (2001a) - has been to assume that there is uncertainty about the ability to migrate, so that of $N$ who acquire education only $\mathrm{p} N(\mathrm{p}<1)$ actually emigrate. If $\mathrm{p}$ were unity, a permanent brain-drain could not be beneficial as all the incremental education would be lost. A further critical assumption is that the probability of migration is fixed and exogenously given for any 
individual would-be migrant. This implicitly arises because foreign firms cannot screen migrants to distinguish the able from the less able and it is this market failure that makes it possible for the brain-drain to be beneficial.

We can illustrate the importance of this assumption, using a highly simplified model which nonetheless captures Mountford's (1997) important insight. Following Beine, Docquier and Rapaport (2001a), assume that ability is uniformly distributed between Amin and Amax and that education yields private returns that increase with ability, as in the line in Figure 1, "with educ". With a given cost of education, people with ability between $A^{*}$ and Amax find it profitable to take education. Now, allow for the possibility of migration for educated people. If an individual can migrate, his or her private returns increase to the line "with educ and mign". With a probability of migration $0<\mathrm{p}<1$, the expected returns to education lie between the domestic and emigration rates of return - say along " $E$ (with educ and mign)", and individuals between $A * *$ and Amax will take education. Of these, however, a proportion, p, will emigrate leaving the domestic economy with $(1-\mathrm{p})\left(A m a x-A^{* *}\right)$ educated people, which may or may not exceed (Amax - $A^{*}$ ). Adding social returns to education is conceptually simple, for they have no immediate effect on private decisions. For simplicity, let social benefits be proportional to the stock of educated workers remaining at home, i.e. $d$ $\left(A \max -A^{*}\right)$ with no migration, and $d(1-\mathrm{p})\left(A \max -A^{* *}\right)$ with migration.

The possibility of migration raises expected welfare for anyone who takes education. Hence there is an increase in aggregate private income, although, of course, some individuals who do not manage to emigrate will regret their education decisions ex post. The uneducated see no direct change in private returns and welfare and consequently gross private income rises when migration is permitted. What happens to aggregate welfare, of course, depends on the social benefits of education.

Fundamental to this story is that every educated individual has probability $\mathrm{p}$ of emigrating - hence all of them experience increased expected returns, so that in our linear example line "E (with educ and mign)" lies uniformly above "with educ". But now suppose that the country or organisation of immigration can screen migrants perfectly for ability. They admit immigrants but only from the top echelons, so that if, say, they want $M$ people from our target country, they get the top $M$ lying between $A_{M}$ and Amax in Figure 2. If this is known in advance, the incentives for individuals with ability below $A_{M}$ are unchanged. The private returns to education follow the thick line in Figure 2. (Amax - $\left.A^{*}\right)$ are educated, of whom $\left(A_{M}\right.$ - $\left.A^{*}\right)$ remain. The increment to total private income is larger than if the migrants had been 
randomly selected, because the same number of migrants makes gains but no-one makes ex post education decisions that they regret. However, there is a loss of social welfare of $d M$.

Clearly perfect screening is implausible, but even with imperfect screening all that would happen is that the vertical section of the thick private returns line would become sloped. But for so long as it meets "with educ" above $A^{*}$, offering migration would affect noone's education decisions. Thus, a necessary criterion for a beneficial brain drain to have any chance of applying is that the marginal person in education has a positive probability of emigrating.

Of course, actual decisions about education are taken with respect to subjective probabilities of migration not ex post observed probabilities. Thus, if individuals are overly optimistic about their prospects, marginal candidates may believe they face improved expected returns even when they do not. In line with most long-run modelling, however, one might wish to discount ever-lasting errors of this sort and presume that eventually subjective probabilities converge to actual ones.

The importance of effective screening is also evident in Stark, Helmenstein and Prskawetz (1997) who distinguish between education and innate ability. For them, the increased incentive to acquire education among less able workers is that, while foreign firms can recognise educational qualifications they cannot, at first, distinguish high from low ability workers. As a result, for a period they offer all migrants with a given level of education the same wage (the mean level averaged over ability for that level of education), with the consequence that less able workers are 'over-paid'. Over time foreign firms may discern workers' true ability and offer 'appropriate' wages, at which time the benefits of emigration erode and, at least with finite probability, the workers return home. Even if they have acquired no skills or networks abroad, they are better educated than they would have been in the absence of migration. In this case it is precisely the imperfections in screening how quickly and with what probability foreign firms discern true ability - that create the incentives to acquire education.

A possible development of the screening model is that the sending or home country has some unexploited capacity for education, in the sense that the returns to education are primarily determined by the demand for skilled workers rather than the ability of the population. In this case even a perfectly screened emigration would generate net benefits. Suppose that as the workers between $A_{M}$ and Amax migrated, they left openings for newly educated workers to take jobs with precisely the same returns. The net effect on the home economy would be that it would have the same number of educated workers as without 
migration and hence the same spillovers, but $M$ fewer uneducated workers. This would raise average incomes slightly (and average skill-levels). In addition, the migrants would record positive private gains. 


\section{Foreign doctors in the United Kingdom}

\subsection{Background}

All doctors working in the United Kingdom have to be registered with the General Medical Council. The General Medical Council records the place where initial qualification was obtained and thus provides some information on the origin of doctors. There are different types of registration status which also give an indication on the post and career progress of the overseas doctor.

The types of status of most relevance for overseas (non-EEA ${ }^{5}$ ) doctors are 'limited' and 'full' registration. Full registration is the normal registration status for UK and EEA doctors who have a medical degree and who have completed their initial period of training or PRHO (pre-registration house officer). Limited registration is initially given to non-EEA doctors (with some exceptions, described below) and allows them to work under supervision until they have proven their clinical ability to be at the level expected from doctors working independently in the United Kingdom. The doctor will obtain limited registration only when he or she has an offer of suitable employment.

The number of overseas (non-EEA) qualified doctors currently in the register is not available (the total number of doctors in the register is $193000^{6}$ ). The number of new doctors arriving from overseas was 2763 in 2000 (32\% of the total number of new registrants), having been as high as around $40 \%$ of the new registrants in the 1990's (General Medical Council, Table 1). The majority of new overseas doctors initially obtain limited registration, although graduates from certain Commonwealth Universities are for historical reasons eligible for full registration immediately. In recent years $25-30 \%$ of those having limited registration have converted it into a full registration every year (General Medical Council). The average period of holding limited registration is just under three years. The main sending non-EEA countries are India and Pakistan.

Another important source of information is the Department of Health Workforce census of NHS medical staff. At present over 100000 doctors are practising in the NHS. Department of Health figures show that approximately $25 \%$ of hospital doctors qualified outside EEA (Table 2).

\footnotetext{
${ }^{5}$ EEA (European Economic Area) doctors (EEA citizens trained in EEA) are automatically guaranteed full registration in the UK.

${ }^{6}$ Not all registered doctors practice in the UK.
} 


\subsection{Routes of Entry for Foreign Doctors}

Migration of overseas doctors to the United Kingdom is closely tied to the postgraduate training system. The aim has been to employ overseas doctors in training posts, thus providing the NHS with employable staff, and simultaneously allowing doctors from developing countries to obtain their postgraduate training that can be subsequently used in their own country. It is also possible for fully trained doctors to work in the United Kingdom, but this route is less common. In the following section we describe the system of medical training in the United Kingdom and the visa and work permit arrangements relevant for doctors and assess the importance of different routes of entry.

Medical education and postgraduate training in the United Kingdom

The initial stage of medical education in the United Kingdom is university undergraduate education, which takes five or six years. Graduation from medical school is followed by a Pre-Registration House Officer (PRHO) year which is still the responsibility of the university and consists of two six month training posts. During this period the trainee is not fully registered with the GMC having only provisional registration.

The next stage of postgraduate training is basic specialist training or the time spent in the Senior House Officer Grade (2-3 years). This stage does not lead to the award of a formal certificate, but after basic specialist training the doctor can work in staff grade posts. The subsequent higher specialist training (4-6 years), which takes place in the Specialist Registrar $(\mathrm{SpR})$ grade, entitles the doctor to be awarded a Certificate of Completion of Specialist Training (CCST). The holders of CCST who are in GMC's specialist register can work as consultants. Entry to higher specialist training is highly regulated and requires admission into a specialist training programme.

In addition to these forms of training, there are arrangements specifically for overseas doctors in the UK that do not lead to any formal qualifications or do not take the form of paid employment. So-called clinical attachments are typically used by foreign doctors to obtain clinical experience in the UK which can help in getting a training post. They can be done without registration and with visitor immigration status but are not paid for and do not provide direct patient access. Clinical attachments normally last between two and four months. 
At higher specialist training level Fixed Term Training Attachments (FTTAs, or type II specialist training posts) provide the opportunity to obtain six months to two years of specialist training for those without indefinite rights of residence in the UK. Unlike standard higher specialist training they do not lead to the award of a certificate.

Not all doctors want to pursue all these training levels and the number of people admitted to training would not even allow this. After basic specialist training a doctor can work at staff grade level posts and after higher specialist training they can be appointed as consultants which is the most senior post. Those specialist-trained doctors who are unable to obtain consultant posts can work as associate specialists.

General Practitioners are trained in a separate vocational training system. This training lasts three years out of which at least 12 months has to be spent in general practice and 12 months in approved hospital posts. GP training often takes place in training schemes. Training abroad can also be taken into account, if considered relevant. The general practice element of GP training requires full registration. There used to be severe restrictions on the availability of funding for doctors who do not have rights of residence or indefinite leave to remain in the UK, but since November 2001 they are eligible for the same funding as UK/EEA applicants.

How foreign individuals enter the system

It is possible for overseas students to undertake undergraduate studies in medicine in the UK medical schools. The number of places is, however, very limited, and the cost for overseas (non-EEA) students is high, approx. $£ 16,500$ per year. Those overseas students who choose to pursue a medical degree can be allowed to stay in the United Kingdom to complete their postgraduate general clinical and basic specialist training.

Most foreign doctors enter the system with an undergraduate qualification from their own country. For the degree to be recognised in the United Kingdom the medical school would have to be included in the WHO list of medical schools. It is usually expected that overseas doctors also complete PRHO or corresponding clinical training in their own country. In order to be able to register in the United Kingdom they will also have to take a Professional and Linguistic Assessment Board (PLAB) test to prove their professional skills, as well as a separate language test (IELTS) if English is not their first language. Those who are part of special placement schemes are, however, exempted from the PLAB. The share of doctors who are exempted from the PLAB of those obtaining initial limited registration has 
been approximately 40\% (Davis 2000). Some other special conditions like completion of basic specialist training to the satisfaction of the appropriate UK specialist training body, appointment to a Type 1 specialist registrar post (i.e. a post approved for training leading to CCST), eligibility for specialist registration or long experience can also qualify the doctor for PLAB exemption. Indian doctors use the PLAB route more often than doctors coming from other countries.

EEA trained doctors who are EEA citizens, as well as graduates from certain universities in Australia, New Zealand, Malaya, Singapore, South Africa, Hong Kong and the West Indies can obtain full registration with the GMC after their PRHO. Other overseas doctors (who have either passed PLAB or been exempted from it) usually get limited registration initially and this allows them to work in the UK under supervision.

Doctors in training have special immigration arrangements: they have so-called permit-free status and thus they do not need a work permit. They can apply for this status after having been appointed to a post. Doctors pursuing PRHO have an initial grant of a maximum of 12 months that can be extended only with special permission. Doctors undertaking basic or higher specialist training for a fixed period are granted permit-free status for the period of training. Doctors participating in basic specialist or general professional training or holding appointments in the SHO grade are granted three years of permit-free status, with possible extension for one year. Similarly doctors qualifying for higher specialist training will be granted an initial period of permit-free training for a maximum of three years with possible extensions. Those doctors who enter career grades (i.e. non-training hospital grades) need a normal work permit that their employer will apply for.

Doctors doing GP training will get the permit-free status for the hospital-based parts of the training but require a training and work experience scheme work permit (TWES) for the year they spend as GP registrars. The NHS funds the GP registrar element of training. Holders of TWES are normally expected to return to their home country after training period, but the Home Office has agreed that those in GP training are not subject to the normal TWES restrictions. They can apply for GP posts in the UK after the training and apply for work permits or to remain in the UK through the Highly Skilled Migrant Programme. Doctors need to have full registration when undertaking GP registrar posts. After training they can apply for salaried jobs for which a work permit is needed. GP principals can apply to remain in the UK through the Highly Skilled Migrant Programme.

Most foreign doctors come to the UK initially for training. The representation of foreign doctors in various training grades in England is presented in Table 3. Note, however, 
that overseas doctors account for the largest share of the workforce in staff grade posts, which do not lead to further certificates or provide specialist training. They are also well represented in associate specialist posts. In such cases formal training has finished but the post-holders have not been able to find consultant posts. This is interesting as the declared aim of most doctors, as well as of the training schemes, is to obtain postgraduate training in the UK.

Among those in training towards GP qualification in England there were only 172 overseas trainees among 1446 registrars (12\%) in 1998. Because the funding system has changed recently, this number is expected to increase in the future.

\section{Evidence of Screening}

Initial screening of overseas doctors entering the United Kingdom takes place through the conditions for registration. Taking the PLAB test incurs costs, as part of it is taken in the United Kingdom. The test consists of two parts, the first of which can be taken in several locations (including India, Pakistan, Sri Lanka and Nigeria), but the second part (the OSCE, Observed Structured Clinical Examination) can only be taken in Britain. The fees for the two exams are $£ 145$ and $£ 430$ respectively. The average pass rate is $59 \%$ for the first part and for part two it is $84 \%$. There is, however, no pre-set pass rate. The PLAB is a qualification, not a part of NHS manpower planning; passing the PLAB does not guarantee employment. (MacDonald 2001.)

Anecdotal evidence also suggests that getting a training post is not straightforward even after passing the PLAB test: in 1998 one district general hospital had 147 applications for four SHO posts, and only four of the applications were from British nationals, two of whom were UK graduates (Sridhar 1998). In 2000 another SHO post attracted 224 applicants of whom 216 were non-EEA graduates (Sridhar 2000). The extent of competition for posts is also largely dependent on the specialty.

A scheme for training placements - the Overseas Doctors Training Scheme (ODTS) was established in 1984 and is a dual sponsorship scheme run by the Royal Colleges and the Department of Health. Initially, the scheme was run by individuals, where a senior colleague from overseas arranged a training post with a consultant in Britain. Currently, overseas doctors apply for the scheme directly to the relevant college. Some colleges are not running the double sponsorship scheme anymore but sponsor overseas doctors independently of the Department of Health through their own placement schemes. Selection is made on the basis recommendations and candidates' experience, but exact requirements vary by college. 
Currently all colleges require at least two years experience in the specialty they wish to practice in, as well as a primary qualification that is acceptable for GMC limited registration. The applicants must not have failed the PLAB. (Constable et al 2002.)

Once accepted to the training scheme, the college acts as the applicant's UK sponsor and the applicant is put onto a waiting list; obtaining a post can take as long as two to three years. Trainees are placed in their first post without formal interview, but for any subsequent posts they have to apply through normal procedures (Gupta \& Lingam 1999). Direct placement has caused concern because it reduces the number of posts that are available thorough open competition (Welsh 2000). In addition to ODTS, the British Council has its own sponsorship scheme which is aimed at doctors with at least three years experience in their specialty. This sponsorship scheme also attracts a large number of applications (Constable et al. 2002).

Returning to the home country

The aim of permit free training as well as of the training schemes is that overseas doctors return to their home country after their training. Staying on in the UK after the training, however, is relatively common. Currently as many as $60-70 \%$ of doctors stay after their training period, although the BMA has expressed a view that this is due to training being inadequate, rather than doctors' reluctance to return to their home country (Davis 2000). Those staying either work in non-training grades or, sometimes, advance to specialist training.

\section{The data}

The data for the current study were collected through interviews and through a postal survey for those who were not reached by telephone or had not provided a telephone number. The total number of responses was 137, 104 of which were the result of interviews and 33 from the postal survey. The questionnaire was originally designed for telephone interviews and thus the responses to the postal survey are more likely to have errors due to misunderstanding of questions ${ }^{7}$.

\footnotetext{
7 The questionnaire has been included as an appendix.
} 
Our sample was obtained from a web-based survey of doctors conducted by the Open University $^{8}$. Some of the individuals responding to this survey provided their contact details and volunteered to participate our study. This survey also covered UK doctors, and in the initial stage the information on the country of origin was separated from the contact details. Those contacted were chosen on the basis of their foreign sounding names (a small sample of English names were also checked to justify this approach). Later it became possible to separate EEA and non-EEA doctors' contact details. We contacted every non-EEA doctor we could identify through these means. The total number of phone numbers provided was $476^{9}$ and there were also 28 contact addresses without phone numbers.

There are at least three sources of sampling error in our sample among UK-based doctors: the participants of the original study may be a selected sample of those from overseas and there is further selection at the stage of volunteering to participate in our survey. Without information about the whole population we cannot infer exactly how these samples are biased. Thirdly, the sample represents only those individuals who have migrated to the $\mathrm{UK}$, and is by no means representative of all doctors in the sending countries.

It is also possible that there were misunderstandings or misinterpretations regarding the questions. Pre-testing did not reveal any major sources of response errors, but particularly the postal survey questionnaires were often incompletely filled, and it is possible that some questions that were answered were not interpreted in the correct way. The response rate in the postal survey was $50.8 \%$.

\section{Results}

\subsection{Descriptive statistics}

The countries represented in the sample are presented in table 3. The main sending country is India, followed by Nigeria and South Africa. Most (75\%) of the immigrant doctors have full GMC registration, and the most common route of entry is PLAB (35\%), the next most important route being ODTS (21\%). The rest either had an EEA degree, had a direct placement or were exempted from the PLAB because their medical degree was recognised.

\footnotetext{
${ }^{8}$ We would like to thank Prof. Janet $\mathrm{G}$ rant from the OU and her team for collecting the list of contacts. 9 Including 'British' names. The total number of 'foreign' contact numbers was 195.
} 
Table 4 displays the means of the main demographic variables in the sample by the income group of the country of origin defined by the World Bank (low income, middle income, high income). We have also separated out Indians into their own group (India belongs to the low-income group in the above classification). Individuals from low-income countries are more typically male and married and they have more frequently dependents. This may be due to the fact that they are also older than doctors from more developed countries. Doctors from middle-income countries more frequently had spouses who were from the UK, whereas for Indian doctors this is very rare. This may indicate different reasons for migrating to the UK (or for staying there). Also the length of experience in home country seems to differ across groups: Indians and doctors from low- income countries have worked for longer periods in their home countries than middle or high-income country doctors. Many high-income countries in this sample are EEA countries, which, given their considerably easier entry to the UK, is not surprising.

Overall, the descriptive statistics suggest that the country of origin, or perhaps more strictly the conditions there, may have some impact on how migrants who enter the United Kingdom are selected ${ }^{10}$. Possibly either motives to migrate or influence of the screening mechanisms differ across countries. Clearly these motives or incentives to migrate are linked to the conditions in the sending country compared to those in the UK, as well as individual career plans and preferences. In the following section we look at more closely the decisions to migrate and how these relate to the characteristics of countries and individuals.

\subsection{Incentives}

In virtually all economic theory migration decisions are based on the incentives to migrate, the benefit from migration (interpreted broadly to include current and future income, working conditions, security etc.) and opportunity cost thereof. The crucial assumption in models of beneficial brain drain is that the expected benefit from migrating is higher for more educated individuals in developing countries, either because net benefit is higher or because the probability of migration is higher. In the following we examine some aspects of incentives to migrate drawing from our data and other available information. We explore information on

\footnotetext{
${ }^{10} \mathrm{Assuming}$ that differences in demographic variables do not reflect those of doctor populations in these countries. It is, however, unlikely that for example doctors in poor countries would have consistently more experience or would be older.
} 
salaries, facilities, reported motives to migrate and how these relate to each other and to the other characteristics of the migrants.

A major issue is naturally the salary differential between home and host countries. In addition to our own survey (which also included questions on relative salaries) we have some official information about doctors' salaries in the UK and India. NHS salaries are based on scales published by the Department of Health. The approximate upper and lower limits of Indian salaries were provided by Dr. Rajesh Chanda. In table 5 we have presented Indian and UK salaries based on these sources. The Indian salaries have been converted into sterling by using the current exchange rate ( $£ 1=$ Rs 76.6$)$.

The UK salaries are considerably higher in nominal terms, with basic salaries 6 to 10 times higher and substantial supplements in addition. When we take price levels into account, however, the differences in salaries narrow considerably. According to the World Bank purchasing power parity conversion factors (2000), prices in India are 5.3 times lower on average than in the UK. Such price level comparisons are rather rough as there are likely to be significant regional differences within large countries, differences in quality of goods and services within countries and questions about the appropriateness of the common consumption basket, especially given that in many cases a high proportion of income is saved (in financial assets) or remitted home as cash payments. Nonetheless while they are not large enough compensate for the salary differential completely, they suggest that the pecuniary incentives for India-UK migration are not overwhelming.

This is also the picture emerging from our survey (Table 6). Interviewees were first asked what percentage of their current salary would they be receiving in their home country if they had stayed at home and had a 'normal' career. Another question concerned the salary they would be earning if they were working in the current grade in their home country. Given that many of the overseas doctors had experienced a reduction in grade or some other change in career upon arrival in the UK, these two could be expected to differ in many cases. Many respondents would not state an exact figure, but were able to indicate the direction of the difference. They were specifically asked to answer the question in monetary terms, without correcting for the price level (although it is possible that some of them despite this answered the question in real terms). Applying the correction for the price level to our figures changes the picture, the Indians' own estimates of their salary in India would give considerable higher real incomes at home than in the UK. This could, of course, reflect a selection bias in migration whereby migrants are on average better than stayers. We return to these screening issues below. 
It also has to be noted that if the money earned in the UK is spent in the sending country (after the spell of migration or through remittances), differences in the monetary value of salaries are the relevant variable. Given the importance of remittances, see below, and the occasional comments by respondents about working in Britain to boost savings or pay off debts, this could be an important consideration. Overall, therefore, we conclude that financial considerations are likely to play at least a certain role in the relocation of doctors to the United Kingdom.

We also asked the individuals about their motives to migrate. Table 7 gives information regarding the motives for migration by country group. Financial advantages were clearly a more common reason for individuals from low and middle-income countries suggesting again that there are positive salary differentials. Most commonly in each group, however, doctors stated advancing their career as a reason to migrate to the UK, although 'Advancing my career' can, of course, include financial considerations as well. Personal reasons were slightly more frequent for the doctors from the high-income countries, which may mean that they are selected on the basis of personal preferences (for example an enthusiasm to travel and live abroad, or marital arrangements, reasons which often came up in the interviews) rather than financial incentives, abilities or professional qualities. On the basis of the salary information presented above high-income country migrants also gain considerably smaller financial advantages from moving to the UK, and they also mention this less often as a motive.

Career concerns are obviously of major importance as motives. Table 8 gives more details on the variables relating to migrant doctors' career progress. Almost half of the overseas doctors (45\%) had experienced a reduction in their grades at migration (this includes those who had to do a clinical attachment upon arrival). Only $10 \%$ had experienced unemployment in their home country, but $27 \%$ had had spells of unemployment in the UK. Individuals from India had the highest incidence of spells of unemployment in both the UK and their home country, and they also had experienced a reduction in grade most often $(63 \%)^{11}$. Only $4 \%$ of doctors from the low-income countries had experienced unemployment in their home countries, but as many as $30 \%$ had been unemployed in the UK. Doctors from middle-income countries had the lowest incidence of unemployment in both the UK and abroad. For high-income country doctors' unemployment spells in the UK were rarer than for those from low-income countries. These data could be interpreted to mean that even given the

11 This figure includes those who had to do a clinical attachment upon arrival in the UK or who took, after having started training in their home country, RMO or research assistant posts. 
higher possibility of unemployment migration still provides returns to low-income country doctors, as the difference in salaries is much larger, or that training in the UK is relatively more useful for their future career. It also seems unlikely that a large proportion of migrant doctors are leaving their home countries because of unemployment, as they face unemployment in the UK much more often than in their home countries. Given that one of the arguments against brain drain is the shortage of doctors that it causes in sending countries, it is, however, significant that as many as $19 \%$ of the major migrant group, Indian doctors, had actually been unemployed in India at some stage of their career.

It is of interest to know whether migration incentives mainly arise from the individual's characteristics or the characteristics of the sending country. The question on reasons for migration does not directly address this, but other questions shed light on conditions in the sending country like facilities or the possibility of finding a training post. On the whole most respondents $(76.7 \%)$ said that the facilities they had before coming to the UK had been good or very good. A majority (58.5\%), however, reckoned that it is difficult or very difficult to find a decent medical training post in their home country. This suggests that career concerns may be more important incentive than the lack of facilities in home country. It also again hints at a selection bias in migration: facilities in low income countries are not generally good or very good by UK standards, so the fact that migrants commonly had them suggest that they were favoured (although some of the respondents may have been responding the question in terms of the level of facilities relative to the average in their own country). Similarly, migration probably selects those most interested in training and advancement, characteristics which are often informally associated with productivity and value as an employee.

Overall, financial advantages and career concerns seem to be the main motive for migration but their importance varies across countries.

\subsection{Return intentions}

In the context of the brain drain the propensity to return is of major importance. Returning migrants potentially bring human capital, networks and technology with them, and the temporary nature of migration can transform the brain drain into a highly beneficial 'brain circulation'. We cannot measure return directly but did survey respondents' return intentions which probably has some correlation with actual returns. Moreover, whether or not 
individuals plan to stay in the target country all their working life is also likely to influence their career decisions and remittances.

In our sample $26 \%$ of respondents reported that they do not intend to return, $41 \%$ do, and $32 \%$ are uncertain. The main difference between the income groups is that in the highincome group fewer doctors intended to return: $50 \%$ of low-income country doctors (and $46 \%$ of Indians) intended to return, whereas this holds for only $17 \%$ of high-income country doctors. The percentage of those who were uncertain varies between $29 \%-36 \%$. In part the differences between groups may reflect the fact that high-income country doctors often have unrestricted rights to stay in the UK because they are EEA citizens.

The reasons mentioned for returning by the respondents are presented in table $9^{12}$. Most commonly they cited family reasons, duty to serve the home country or because they do not want to settle in the UK. The high-income country doctors typically mention reasons different from other groups, but the number respondents in this group who intended to return is very small. The most common reasons for not returning are working conditions, facilities and the standard of living ${ }^{13}$. The Indian, low-income and middle-income doctors mention better working conditions and facilities more often, whereas working relationships and family reasons are often cited by the high-income doctors. As expected, the standard of living is mentioned most often by the low-income country doctors.

In many developing countries the quality of facilities provided by the public and private sectors differs a lot, as it does between rural and urban sectors. The private sector also typically provides possibilities for higher salaries, at least for senior doctors, as illustrated by the Indian salary figures presented above. We asked the respondents who intended to return to their home country whether they intend to work in the public or private sector i) immediately after their return and ii) five years after their return. Of those who intended to return, the majority intend to work in the private sector after their return (immediately after return $55.4 \%$, five years after return $64.8 \%{ }^{14}$ ), and a huge majority $(89.3 \%$ ) intend to work in an urban $\operatorname{area}^{15}$. The percentage of Indian doctors who intend to work in the private sector

\footnotetext{
${ }^{12}$ The respondents could indicate for each reason whether or not this has influence on their decision to return, the number of positive responses was not restricted.

${ }^{13}$ The missing observations are due either to respondents saying that they do not know if the particular reason will be relevant for return decision, or to unclear postal questionnaire responses. Some individuals had also filled in the postal questionnaires to state reasons for not returning although they had initially said that they do not know if they intend to return; these are not reported above.

${ }^{14}$ These figures include some respondents who say they will work in both public and private sector, without them the figures are $48.2 \%$ and $55.6 \%$ respectively.

${ }^{15}$ Without those who intend to work in both sectors $85 \%$.
} 
after their return immediately is $76.9 \%$ and in five years time similarly $76.9 \%{ }^{16}$. These figures suggest that migration and return decisions are driven by career concerns. The sectoral issues will be discussed in more detail in later sections.

The overall conclusion from these figures is that by no means all developing country doctors come to the UK to stay. Despite the salary differentials and better facilities a fair number of them intend to return. The returnees, however, are not very likely to work in impoverished rural areas. It is possible, however, that although the returning doctors themselves work in urban areas, they "push" incumbent doctors out into the rural labour market.

\section{$5.4 \quad$ Screening}

As pointed out in the theoretical discussion, whether or not migrants are effectively screened, is of major importance for the implications of the beneficial brain drain hypothesis. Several questions in the questionnaire attempt to assess the quality of the migrants, for example those regarding the class of the degree, the institution where it was obtained (at least in those countries where applicants choose the university they apply to), salary etc. However, most of these can reflect the degree of screening adequately only if the individual characteristics and the sample statistics can be compared with those from the population that remains in the sending country. In our case this is not possible, with some exceptions that are discussed towards the end of this section. Thus we have to construct measures of screening either by using individuals' own assessments of their qualities compared to those of doctors in general in their home country or by using information available from other sources to infer something about the population in general as we did in the discussion of Indian salaries above. The fact that our sample may be a selected sample of overseas doctors has to be taken into account when assessing the methods. Those who manage to migrate to the UK are already a selected sample, and the fact that sampling was based on voluntary participation is another source of selectivity. In the first method the subjectivity of the responses must also be considered as a shortcoming.

The first test we conducted concerns the association between the respondents' opinion on how difficult it was for his or her last employer at home to replace them. More specifically we want to see if doctors tend to think that replacing them is more difficult for

${ }^{16}$ Without those who intend to work in both sectors the figures are $69.2 \%$ and $65.4 \%$. 
the employer than is finding suitably qualified applicants in general. If this were the case, we could interpret it as a sign that individuals in the UK sample think they are better than the home country average. However, there is a possibility that the opposite outcome (doctors think they can be replaced more easily than in general) is also a result of screening because the doctors who are good enough to migrate tend to hold posts that are generally considered as more desirable. Where the doctors worked prior to migration also has implications for how easily they can be replaced: if migrant doctors are disproportionately from urban areas or private sectors they would probably be easier to replace.

In Table 10 we have presented the frequencies of observations for each combination of responses. The total number of observations is for which there is a response for both question is 88 , although if we consider only those whose last job before the UK was in their home country there are only 84 complete responses to both questions (for the purpose of the symmetry test these are, however, essentially the same, as the only difference is on the diagonal). 99 individuals responded the question about replacement (29 had not been employed recently in their home country before coming to the UK and 7 said they nevertheless did not know how difficult it was for their last employer in home country to replace them), and 121 responded to the question about the difficulty of finding applicants. There was a minor mistake in the interviewing process and 3 respondents were not asked this question. Also several respondents (2 of whom had not recently worked in their home country) said they did not know what the situation was for employers in their home country.

We conduct a test of the symmetry of this table by assuming that it is symmetric around the diagonal, and the calculating the expected frequencies for each off-diagonal cell $(i, j), i \neq j$ where i denotes row and $\mathrm{j}$ column. The actual frequencies can then be compared with the expected ones by calculating a Chi-squared statistic. However, given that it relies on squared differences between frequencies this test does not test directly whether the upper or lower triangle is higher.

There are minimum conditions for applying the Chi-squared test, as the test is exact only when sample size goes to infinity, but these differ by author ${ }^{17}$. By most accounts, however, our tests are, at best, on the very margin of acceptability: we can use only those cells for which the expected frequency is more than zero, so are five degrees of freedom; the

\footnotetext{
${ }^{17}$ Wickens (1989), for example, has compiled the following list of minimum conditions:

1. For tests with one degree of freedom the expected frequency should exceed two or three.

2. With more degrees of freedom expected frequency of one in some cells is tolerable.

3. In large tables up to $20 \%$ of the cells can have expected frequency less than one.

4. The total sample should be at least four or five times the number of cells.

Samples should be appreciably larger when the marginal categories are not equally likely.
} 
expected frequencies in two pairs of cells are less than one, which accounts for $40 \%$ of cells; the total sample used in this test was only 31. As noted below the table, the hypothesis of symmetry cannot be rejected on the basis of the chi squared test (probability, $p=0.24$ ).

We also tested the probability of a certain number of observations lying above and below the diagonal (proportion test). Since we are not interested in precisely where in the upper or lower triangles the observations lie we take the number of off-diagonal observations (31) as given and test the null hypothesis that the probability of any observation falling above the diagonal is 0.5 . The probability of 14 or fewer observations below (or 17 or more above) in this case is $36 \%$, so again we cannot reject the null hypothesis.

Another test of screening concerns the difficulties of finding a job in the UK (table 11). If respondents consider that finding a job in the UK was easier for them than for doctors from their country in general, this could be regarded as a sign of screening (presuming that their assessments are correct). There is, however, a question of how respondents interpreted 'difficulty to find a job': it is also dependent on luck, and thus naturally those who have indeed found jobs have been luckier than those who have not (and have not been observed).

Again we tested the symmetry of the table and this time Chi-squared indeed confirms that it is unlikely that the table is asymmetric by of pure chance $(\mathrm{p}=0.0002)$. In this case there is only one pair of cells for which the expected frequency is below one. Also the total number of observations is five times more than the number of cells included in the test. The requirements for chi squared test are thus more fully satisfied. The proportion test using binomial distribution shows that the allocation of observations below and above is also very unlikely to be random in this case $(\mathrm{p}=0.000097)$.

Similarly, respondents' assessments of the difficulty of finding placements (in ODTS or direct placement programme) in their personal experience or in general (table 12) could reflect the efficiency of screening, as selection to these programmes is another main channel (in addition to PLAB) for overseas doctors to enter the UK. The cross-tabulation seems asymmetric, but the chi-squared suggests that there is no conclusive evidence of responses to the two questions to be systematically asymmetric $(\mathrm{p}=0.107)$. The number of individuals coming to the UK through these schemes in our sample is, however, relatively small, and the chi-squared test is unlikely to be applicable in this case. The test based on binomial distribution, on the other hand, strongly rejects the hypothesis of symmetry, suggesting that migrants found it easier to find placements themselves than they believed general conditions at home would warrant. 
The respondents were asked about the institute from which they obtained their degree. The number of observations from most countries is too small to draw any conclusions but the number of Indian doctors in the sample is 58 , which should be adequate to check whether migrants have a typical profile across institutes. The Indian system also allows students to choose the university they apply to, so the question of 'good' universities is relevant. There are no official rankings of Indian universities, but since 1998 India Today magazine has published listings of 10 (in 1998 five) top medical colleges. According to our estimate (in some cases there was some uncertainty over which college the respondent had gone to, although they mentioned the university) 15 out of 58 (26\%) of the Indian respondents had obtained their qualification from the colleges mentioned in the four ranking lists available. The share of these colleges out of total admissions is (in 2002) 1840 out of 20777. If we assume that the respondents are randomly selected the probability that 15 or more individuals in the sample of 58 would be from these colleges is $0.01 \%$, the expected value being five.

A problem associated with the test above is that those coming from the top universities are in general older and have more experience in India before coming to the UK. Given the fact that medical education in India has expanded considerably during the last decades and that a large part of that increase has been due to new private institutions (Jayaram 1995), it is possible that the top universities accounted for a much larger proportion of medical graduates in the past. The test above would thus give too small a probability for the observed share of graduates from those schools. We have no detailed information about the exact number of graduates from different colleges over time. However, the number of doctors in India increased by 82\% between 1986 and 2001 (Medical Council of India).

We also wanted to see if having obtained a degree in one of the top universities is related to the grade the individual has attained before coming to the UK. Without controlling for experience, there seem to be more consultants among those who graduated from the top universities - with a chi-squared statistic significant at $1 \%$ level $(\mathrm{p}=0.01)$. However, those who come from top universities also had more experience on average (7.6 years as opposed to 4.9) before coming to the UK. Due to a very small sample, it is not possible to examine association separately between grade and university for each level of experience. Instead, we estimate an ordered probit model for grade attained (before coming to the UK). This is done for Indian doctors only, excluding those whose grade is 'other'. In addition to experience we used gender, grade of degree, age and years worked in the private sector as explanatory variables - see Appendix 2. The coefficient of top university attendance is in fact negative in this relationship, but not at all significant $(\mathrm{p}=0.788)$. This was the case also for models with 
fewer explanatory variables. Thus the relationship between grade and top university attendance seems largely due to the factors that explain grade (viz. years of experience) being correlated with having attended a top university. Nonetheless, the fact that doctors from the best institutions are over-represented among migrants remains indicative of screening.

We have also conducted a test regarding the association between difficulties of finding a decent training post and the level of facilities before coming to the UK (table 13). If the individuals sampled are selected from good institutions, it is likely that even when they come from countries where facilities are generally poor, migrating doctors will come from institutions with good facilities. However, as we do not have information on the level of facilities in general (but only of those who migrate) we cannot test whether there is significant difference or not.

There is negative association, as expected, between the difficulty of finding a medical training post and level of facilities. Correlation coefficients for ordinal variables like Kruskal and Goodman's gamma (-0.1588 in this case) and Kendall's tau (-0.1060) are negative. The asymptotic standard errors of these correlation coefficients, however, are so high (0.148 and 0.099 , respectively) that they are not significantly different from zero. The chi-squared on the contingency table in Table 13, on the other hand, shows that the variables are not independent $(\mathrm{p}=0.001)^{18}$

We also wanted to see if, after controlling for country specific variables, those individuals who had good facilities were somehow "better" ${ }^{\prime 19}$. We explained the quality of facilities at home by an ordered probit model with several country variables - income group, difficulty to find a decent training post, general difficulty to find qualified applicants. We then calculated the predicted level of facilities due to these country variables and interpreted the residual over- or under-performance as dependent on individual doctor's skills. Finally we checked whether this residual had any association with the other measures of ability of a doctor. The only significant (at 5\% level) association was with the dummy indicating whether migration possibilities had influenced the choice of specialty: those who faced worse facilities than predicted seemed to admit more often that their choice of specialty had been affected by the prospect of migration (the reverse seems to hold for those who had unusually good facilities). There was no association with grade, unemployment, gender, route of entry,

\footnotetext{
${ }^{18}$ Note that Kendall's tau and G oodman and Kruskal's gamma measure whether individuals are ranked in the similar or different manner in the two categorisations. Thus, they measure certain type of dependence rather than dependence in general. Thus it is not contradictory that chi squared shows that are not independent and these coefficients are not of significant magnitude.

${ }^{19}$ The results of this and other estimations mentioned below are reported in the appendix.
} 
having an excellent degree or having attended a top university. This outcome appears to suggest that access to good facilities offer us very little information about doctors' individual abilities, but that those who intend to train in their specialty abroad, are not concerned about the bad level of facilities in their home country.

Considering the above tests, it is also of interest to see if respondents' assessments of the general difficulty of finding a job or a decent medical training post are consistent for each country. India is the only country for which we have large enough number of observations to make sensible comparisons. The results show that $71 \%$ of the sample thinks it is difficult or very difficult to find a decent medical training post, $85.7 \%$ think it is easy or very easy for employers to find applicants and $82.7 \%$ thinks it is difficult or very difficult for Indians to find a job in the UK. These figures, especially the last two, show a high degree of consistency, which suggests a fair degree of reliability.

Given that the screening mechanism involves an official component which is aimed at selecting high quality doctors, it is of interest to see if this official mechanism measures qualities that are similar to those used in screening inside home countries. The two main routes for overseas (non-EEA) doctors are the PLAB test and Overseas Doctors Training Scheme (or other direct placement schemes), as described above.

We looked at relationship between how may times an applicant had attempted the PLAB and his or her grade and class of medical degree, and between how difficult it was for the applicant to find a post in the UK and his or her grade before coming to the UK and class of degree. There was no significant association in any of these tests. It is, of course, still possible that migrant doctors are different from those who are left behind. Screening in the UK, however, does not seem to have one-to-one relationship with observable measures of success in migrants' home countries. It has to be noted though, that very senior doctors can be exempted from PLAB on the basis of their experience, and thus the most successful doctors who have already obtained postgraduate training would not face the choice of route. The number of such doctors in our sample is relatively small, however ${ }^{20}$.

PLAB and ODTS are different methods of screening individuals and it would be interesting to see if success in them is related to the measures of individual's ability. We compared the percentage of individuals choosing either oute among Indian doctors by splitting the sample by the university status. We excluded the individuals who had used other

\footnotetext{
20 It seems that there are 12 individuals who had their qualification recognised without passing PLAB or entering a training scheme. This figure does not include those whose qualification was known to be recognised because of the training institution.
} 
routes. It seems that ODTS is indeed more common among individuals from top universities, but the chi-squared test indicates that this is not significant $(\mathrm{p}=0.331)$. If we only include those whose had more than six years of experience (and who then could have realistically used the ODTS route), the relationship is nearly but not quite significant $(p=0.112)$, but the number of observations is also very small (21). Estimating a probit model on whether or not the individual had chosen ODTS (Indian doctors) showed that having SpR, consultant or "other" grade status increases significantly the probability of entering thorough ODTS route. The other explanatory variables (top university, excellent degree, experience before entry to the UK, entry cohort) did not have significant effects. This may reflect the ability of ODTS to identify 'high-fliers' independently of the 'objective' measures of ability that we can identify.

When we estimated the same probit model for the whole sample of those who had entered through PLAB and ODTS, SpR and other grades had positive and significant effect on choosing ODTS (consultant grade predicted ODTS perfectly and was dropped), and having an excellent degree also had a positive coefficient that was almost significant at $10 \%$ level $(\mathrm{p}=0.104)$. India as a source country had negative but not statistically significant coefficient. Having attended an Indian top university had positive but not significant effect. Thus, there seems to be some relation between the ability of a doctor (or at least his or her subsequent success) and choosing ODTS.

As mentioned above, investigating the selection of migrants fully would actually require knowledge of the characteristics of the total population of doctors in the sending country. It is likely that if we had this information we could for example infer something on the basis of which sector the respondents had worked prior to entering the UK. A very high percentage $(86.6 \%)$ of respondents had last worked in an urban area in their home country ${ }^{21}$. $33.9 \%$ had worked in the private sector just before they $\operatorname{left}^{22} .36 .8 \%$ of Indian doctors had worked in the private sector before coming to the UK. In high and middle-income countries a smaller fraction of doctors (25\%) than in low income countries $(39.1 \%)$ had worked in private sector just before coming to the UK (given that they had actually worked in their home country immediately before the $\mathrm{UK})^{23}$.

Despite the shortcomings of the data there is some evidence of screening of migrants. The respondents clearly feel that they were more successful in finding jobs in the UK than doctors from their home countries in general. A disproportionately large number of the Indian

$213.57 \%$ had worked in both sectors, they are included in this figure.

$223.57 \%$ had worked in both sectors, they are included in this figure.

${ }^{23}$ Excluding those who worked in both sectors the figures are 25\%, 10\% and 34.8\%. 
doctors in the sample have obtained their degrees from elite institutions. The Overseas Doctors' Training Scheme seems to select consistently more able or successful doctors. With a high level of certainty we can conclude that there is positive correlation between the quality of a doctor and his or her possibilities of getting through both the official screening system and finding a job in the UK. In addition we have already noted the smaller UK-India salary differential among migrants than in general, the costs of PLAB and the high demand for posts in the UK among overseas doctors. All this amounts to pretty clear evidence that potential medical migrants to the UK are effectively screened, and thus that the influence of the possibility of migration on educational decisions is not the same for all levels of ability (assuming that individuals are rational and have correct information on their ability and opportunities). In the next section we look more closely at the educational responses to migration possibilities.

\subsection{The educational response to migration}

A crucial point in the theory of beneficial brain drain is the assumption that the possibility of migration influences decisions on education. We investigated this issue by asking a straightforward question on whether the possibility of migration had influenced the respondent's decisions. It is of course possible that the respondents do not answer the question honestly: especially in countries where brain drain is considered as a major problem, it may be regarded as 'immoral' to plan migration when taking up state-funded education. We also asked, therefore, if the respondents thought that doctors in general in their country were thinking of the possibility of migration when making certain decisions. This question might give more reliable answers to whether the respondent him or herself had taken the possibility of migration into account.

In table 14 we have presented the averages of responses to the question whether the individual had considered migration when making certain decisions, and whether they believe others in their country do so in general.

There were some missing observations, almost all of which were due to the respondent saying that they do not know what the doctors in their country think in general. For postal questionnaires there were two unclear responses for questions regarding personal decisions. For the sake of comparability the averages here were calculated for those who had answered on all the possibilities offered in the questions. 
An interesting observation is that for individuals from high income countries larger (or roughly the same) percentages of respondents said that the possibility of migration had had an influence on their own decisions as said the same for doctors in general. In the other country groups the opposite is typically the case. This could suggest that migrants from highincome countries are people for whom migrating is a goal itself and that in those countries the general incentives to migrate are weak.

We also created a union variable indicating if the respondent answered 'yes' to any of these 'influence' questions. We then compared this variable with certain characteristics. There is no association between income group and admitting to thinking of migrating, nor between the size of the country and thinking of migrating. The above observation of the differences between the country groups by income is, however, also true for the union variable.

We can also examine the relationship between migration intentions and the characteristics of the individuals. There was no association between migration having an impact on their decisions and any of the explicit reasons to migrate considered in table 15 . Neither was there any association between the grade held before coming to the UK or class of the degree and the impact of migration on decisions. For the sub-sample of Indian doctors we also cross-tabulated the university status (top ten university or not) and whether or not the possibility of migration had influenced migrant's decisions. Those who went to the Indian top universities admitted less often that the possibility of migration was influential. The chisquared test, however, indicated that this was not significant $(\mathrm{p}=0.225)$. There was no association between sending remittances and return intentions and having considered migration when making decisions. There seems, however, to be some association between the difficulty of getting a decent training post and migration having influence on decisions (Table 16). If the doctors are aware of this difficulty before taking decisions it is natural that they might consider migrating and also take this into account when making the decisions.

Clearly it is not true that potential migrants never consider migration when making decisions on education and career. Equally clear, however, is that not all do so - either for intrinsic reasons or perhaps because they believe that screening would preclude their gaining from such possibility. (Of course, in our sample of migrants, such a belief would be false.) The critical issue is whether the pro-education effect is large enough to cause the total effect of the brain drain to be beneficial. The following simple calculation considers how large an effect of migration on education decisions would be required to produce a beneficial brain drain, and how large a degree of screening would influence this. 
Suppose there were no screening and that migrants are randomly drawn from the population of doctors. Suppose that $40 \%$ of doctors are 'influenced' to train in medicine by migration - about what we observe - and that this means that in the absence of migration there would be $40 \%$ fewer doctors. Suppose the actual migration rate is $20 \%$ as for India, so that of each 100 doctors trained, 80 remain at home. The net benefit is thus $(80 \mathrm{~b}-100 \mathrm{c})$ where $b$ is benefit and $c$ is cost of training doctors. Without migration net benefit is $60(b-c)$, so the net gain from migration is thus $(20 b-40 c)$, which is positive if $b>2 c$.

If we now relax the assumptions, and reduce the 'influence rate' to $10 \%$, migration will inevitably lead to losses. Similarly, if the migration rate is $40 \%$ (or more) migration, even with a $40 \%$ influence effect losses will result. For small countries it is quite realistic to assume this rate of migration among highly educated individuals (see, for example, Carrington and Detragiache 1998). Also, the 'influence rate' obtained from our survey is not strictly speaking the proportion of individuals who would have not trained as doctors in the absence of migration, but only those who reported that migration possibilities had had some influence on their decisions. Even if the 'real influence rate' were half of this, 20\%, migration would result in losses for the sending country.

If we take into account screening, the picture becomes much less positive for the possibility of beneficial brain drain. Even though among actual migrants the 'influence rate' is $40 \%$, a much smaller percentage of those who remained at home seem likely to have chosen to educate themselves due to the possibility of migration. If we assume that the influence rate among 'stayers' is $10 \%$ and among migrants $40 \%$, the total number of doctors in the absence of migration in the above scenario is 84 . The net benefit of migration in this case is inevitably negative.

Given the figures we have found in our survey, this example suggests that the education channel for the beneficial effects of brain drain is not particularly plausible. However, when assessing whether the brain drain is indeed costly for the sending country, we also have to take into account other issues like the duration of migration and return migration. These are discussed in the next section.

\subsection{Other issues}

As far as the costs and benefits of the brain drain are concerned, the means of financing education, the flows of remittances and the sector in which the individuals would work if they returned (or the sector they left), are all interesting. We asked respondents to report the main 
sources of their funding (those that accounted more than $25 \%$ of the total cost) of their education (table 16). Most doctors had used private means to finance their education, and a high percentage had also received free or highly subsidised education ${ }^{24}$. In the middle income countries the respondents had less often received free education, and they also had got scholarships and borrowed money more often than the other groups. Clearly there would be some degree of lost public investments for the sending countries if all these doctors stayed abroad.

Remittances can be a considerable source of income for developing countries. $45 \%$ of the individuals interviewed send remittances to their home country. These remittances were on average $16 \%$ of their income in the UK the lowest level of remittances $8 \%$ being in middle-income countries, and the highest, $22 \%$, in low-income countries (not all individuals gave precise percentage, and this figure might be overstated as those sending very small or irregular payments are not included). For low and high-income countries the percentage of income that remittances account for is higher than for middle-income countries. The purpose of the remittances is most typically supporting relatives and saving. There are considerable differences between individuals from different country groups: saving is the most common motivation for remittances in high-income countries but in low-income countries supporting relatives is much more important (Table 17). Those who intend to return send remittances more often, and among those who reported the percentage that remittances are of their income, they were also higher for individuals who intend to return to their home country.

As the thickness of the labour market may have important implications for the costs of the brain drain, we have also sudied the connection between country size and certain variables. The sample was split into two by defining population over 20 million as 'large' (definitions based on 10 and 15 million produced too small number of individuals from 'small' countries for grouping to make any sense). A large majority of the migrants studied, however, come from large countries (119), and comparison of large and small countries did not reveal any remarkable differences in demographic characteristics or careers of the doctors. On the basis of the small number of individuals from small countries, it seems that they thought it was not more difficult for their employers in their home countries to replace them, nor was it more difficult for employers to find suitably qualified applicants. None of them had experienced unemployment in their home country whereas $12 \%$ of those from large

\footnotetext{
24 O nly completely free education was given as an option in the questionnaire, but as it emerged during the interviews that many had paid nominal tuition fees, highly subsidised education was also included in that option. The responses to postal questionnaires can be different in this respect.
} 
countries had, so this may provide some support for the assumption that losses of skilled labour are more likely to be harmful for small countries.

\section{Conclusions}

We have investigated overseas doctors in the UK to discover the effects of the migration of high-level health personnel on the sending country. Theory shows that the extent to which the possibility of migration affects individuals' education decisions, and how carefully migrants are screened are of paramount importance for the implications of migration.

Our results suggest only relatively weak links between migration possibilities and training. Some respondents, but by no means all, admit that the possibility of migration influenced their decisions. The conditions in the sending country clearly have an impact on the motivation and characteristics of migrants, and migration decisions are also obviously based on different motives in high- and low-income countries. There does not, however, seem to be an association between migration having influence on decisions and individual characteristics.

There is also clear evidence of screening. In addition to the official mechanisms through which a doctor has to pass to gain the right to practice in the UK, our data suggest that the process of obtaining a job in the UK also serves as a considerable screening mechanism. For example, the doctors interviewed often reckoned that they had passed into the system more easily than average, and the Overseas Doctors' Training Scheme seems to select consistently more able or successful doctors. A large number of the Indian doctors in the sample obtained their degrees from top institutions and they appear to have had smaller increases in their incomes as a result of migration than would be indicated by average pay ranges in India and Britain.

Both pieces of evidence cast doubt on the possibility of large-scale benefits from the brain drain through its effects on education incentives. In other relevant dimensions, our data on overseas doctors in the UK show that a considerable number of them had received free or highly subsidised education. A large fraction, on the other hand, also sends remittances to their home country. Overall, therefore, it is still possible that the brain drain is beneficial through these other effects, although, so far, it is unclear what the total effect is. 


\begin{tabular}{|l|cccccccccccc|}
\hline $\begin{array}{l}\text { Country of } \\
\text { qualification }\end{array}$ & 1989 & 1990 & 1991 & 1992 & 1993 & 1994 & 1995 & 1996 & 1997 & 1998 & 1999 & 2000 \\
\hline United Kingdom & 3568 & 3706 & 3620 & 3618 & 3687 & 3701 & 3845 & 3967 & 4030 & 4243 & 4304 & 4457 \\
EEA (excl. UK) & 1315 & 1194 & 1190 & 1352 & 1490 & 1856 & 2144 & 2435 & 2022 & 1730 & 1512 & 1380 \\
Non-EEA & 3110 & 3151 & 3671 & 3653 & 4043 & 3487 & 3978 & 4690 & 4238 & 3826 & 2857 & 2764 \\
\hline
\end{tabular}

Table 1. First time registrations. Source GMC

\begin{tabular}{|l|c|c|c|c|c|}
\hline & All & UK & EEA & Non-EEA & $\begin{array}{c}\text { Share of } \\
\text { Non-EEA }\end{array}$ \\
\hline All Grades & 67838 & 46205 & 3662 & 17971 & $26.5 \%$ \\
\hline Consultant & 24404 & 18991 & 1243 & 4170 & $17.1 \%$ \\
\hline Staff Grade & 4803 & 1344 & 295 & 3164 & $65.9 \%$ \\
\hline $\begin{array}{l}\text { Associate } \\
\text { Specialist }\end{array}$ & 1552 & 544 & 50 & 958 & $61.7 \%$ \\
\hline $\begin{array}{l}\text { Registrar } \\
\text { Group }\end{array}$ & 12648 & 8093 & 875 & 3680 & $29.1 \%$ \\
\hline $\begin{array}{l}\text { SHO } \\
\text { House } \\
\text { officer }\end{array}$ & 15384 & 9970 & 765 & 4649 & $30.2 \%$ \\
\hline
\end{tabular}

Table 2. Percentage of hospital doctors by different countries of origin in England in

September 2001. Source: NHS Workforce census. 


\begin{tabular}{|l|c|c|}
\hline COUNTRY & Freq. & Percent \\
\hline Armenia & 1 & 0.73 \\
Australia & 3 & 2.19 \\
Bangladesh & 1 & 0.73 \\
Botswana & 1 & 0.73 \\
Bulgaria & 1 & 0.73 \\
Burma & 2 & 1.46 \\
Colombia & 1 & 0.73 \\
Egypt & 2 & 1.46 \\
Germany & 11 & 8.03 \\
Ghana & 1 & 0.73 \\
Greece & 2 & 1.46 \\
Guayana & 1 & 0.73 \\
Holland & 1 & 0.73 \\
Hungary & 1 & 0.73 \\
India & 58 & 42.34 \\
Iran & 1 & 0.73 \\
Iraq & 1 & 0.73 \\
Ireland & 1 & 0.73 \\
Italy & 1 & 0.73 \\
Kenya & 1 & 0.73 \\
Malaysia & 5 & 3.65 \\
Nepal & 1 & 0.73 \\
Nigeria & 10 & 7.3 \\
Pakistan & 6 & 4.38 \\
Russia & 1 & 0.73 \\
Singapore & 2 & 1.46 \\
South Africa & 9 & 6.57 \\
Spain & 2 & 1.46 \\
Sudan & 3 & 2.19 \\
Trinidad \& & 3 & 2.19 \\
Tobago & 2 & 1.46 \\
Uganda & 1 & 0.73 \\
Yugoslavia & & \\
\hline
\end{tabular}

Table 3. Distribution of countries of origin in the sample 


\begin{tabular}{|c|c|c|c|}
\hline India & No. Obs. ${ }^{a}$ & Mean $^{b}$ & Std. Dev. \\
\hline Woman & 58 & 0.26 & 0.44 \\
\hline Age & 58 & 34.02 & 6.19 \\
\hline Married & 58 & 0.86 & 0.35 \\
\hline Spouse from UK & 50 & 0.06 & 0.24 \\
\hline Spouse lives in UK & 50 & 0.88 & 0.33 \\
\hline Dependents & 58 & 0.52 & 0.50 \\
\hline $\begin{array}{l}\text { Total experience in } \\
\text { home country, years }\end{array}$ & 57 & 5.36 & 3.62 \\
\hline $\begin{array}{l}\text { Total experience in } \\
\text { the UK, years }\end{array}$ & 57 & 4.06 & 3.82 \\
\hline \multicolumn{4}{|l|}{ Low income } \\
\hline Woman & 28 & 0.18 & 0.39 \\
\hline Age & 28 & 34.89 & 6.11 \\
\hline Married & 28 & 0.82 & 0.39 \\
\hline Spouse from UK & 23 & 0.22 & 0.42 \\
\hline Spouse lives in UK & 23 & 0.96 & 0.21 \\
\hline Dependents & 27 & 0.67 & 0.48 \\
\hline $\begin{array}{l}\text { Total experience in } \\
\text { home country, years }\end{array}$ & 28 & 3.79 & 3.55 \\
\hline $\begin{array}{l}\text { Total experience in } \\
\text { the UK, years }\end{array}$ & 28 & 4.73 & 5.06 \\
\hline \multicolumn{4}{|l|}{ Middle income } \\
\hline Woman & 28 & 0.36 & 0.49 \\
\hline Age & 28 & 33.14 & 4.57 \\
\hline Married & 28 & 0.64 & 0.49 \\
\hline Spouse from UK & 18 & 0.39 & 0.50 \\
\hline Spouse lives in UK & 18 & 1.00 & 0.00 \\
\hline Dependents & 28 & 0.50 & 0.51 \\
\hline $\begin{array}{l}\text { Total experience in } \\
\text { home country, years }\end{array}$ & 26 & 3.00 & 2.43 \\
\hline $\begin{array}{l}\text { Total experience in } \\
\text { the UK, years }\end{array}$ & 27 & 3.22 & 1.90 \\
\hline \multicolumn{4}{|l|}{ High income } \\
\hline Woman & 23 & 0.52 & 0.51 \\
\hline Age & 23 & 33.87 & 4.70 \\
\hline Married & 23 & 0.39 & 0.50 \\
\hline Spouse from UK & 9 & 0.22 & 0.44 \\
\hline Spouse lives in UK & 9 & 1.00 & 0.00 \\
\hline Dependents & 23 & 0.26 & 0.45 \\
\hline $\begin{array}{l}\text { Total experience in } \\
\text { home country, years }\end{array}$ & 22 & 1.93 & 2.48 \\
\hline $\begin{array}{l}\text { Total experience in } \\
\text { the UK, years }\end{array}$ & 23 & 5.15 & 4.06 \\
\hline
\end{tabular}

Table 4. Means of the main demographic variables by country group

\footnotetext{
a The questions on whether the spouse is from the UK and whether he/ she lives there were only asked if the respondent was actually married.

b For variables other than age or experience the mean equivalent to the proportion of respondents having the characteristic in question.
} 


\begin{tabular}{|c|c|c|c|c|c|}
\hline \multirow{2}{*}{$\begin{array}{l}\text { Level (UK } \\
\text { grade) }\end{array}$} & \multicolumn{2}{|l|}{ UK (NHS) } & \multirow{2}{*}{$\begin{array}{l}\text { India, } \\
\text { government } \\
\text { sector }\end{array}$} & \multirow{2}{*}{$\begin{array}{l}\text { India, private } \\
\text { practice }\end{array}$} & \multirow{2}{*}{$\begin{array}{l}\text { India, private } \\
\text { hospitals }\end{array}$} \\
\hline & Basic salary & Supplements & & & \\
\hline $\begin{array}{l}\text { Junior } \\
\text { level }(\mathrm{SHO})\end{array}$ & $£ 23,190-£ 32,520$ & Up to $100 \%$ & $£ 2,351-£ 5,485$ & & $£ 2,351-£ 4,702$ \\
\hline $\begin{array}{l}\text { Middle } \\
\text { level }(\mathrm{SpR})\end{array}$ & $£ 25,920-£ 37,775$ & Up to $100 \%$ & $£ 3,135-£ 7,053$ & & \\
\hline $\begin{array}{l}\text { (Staff } \\
\text { grade) }\end{array}$ & $£ 28,150-£ 41,980$ & & & & \\
\hline $\begin{array}{l}\text { Senior } \\
\text { level, } \\
\text { specialist } \\
\text { (consultant) }\end{array}$ & $£ 52,640-£ 68,505$ & $\begin{array}{l}\text { Discretionary } \\
\text { points up to } \\
£ 21,960 \text { or } \\
\text { distinction } \\
\text { awards up to } \\
£ 65,080\end{array}$ & $£ 3,918-£ 6,531$ & $£ 3,265-£ 7,837$ & $£ 3,265-£ 10,449$ \\
\hline $\begin{array}{l}\text { (associate } \\
\text { specialist) }\end{array}$ & $£ 31,210-£ 56,105$ & $\begin{array}{l}\text { Discretionary } \\
\text { points up to } \\
£ 8,420\end{array}$ & & & \\
\hline
\end{tabular}

Table 5. Salary scales in the UK and India 


\begin{tabular}{|c|c|c|c|c|c|c|c|c|}
\hline & \multicolumn{2}{|c|}{ India } & \multicolumn{2}{|c|}{$\begin{array}{c}\text { Low income } \\
\text { countries }\end{array}$} & \multicolumn{2}{|c|}{$\begin{array}{l}\text { Middle Income } \\
\text { countries }\end{array}$} & \multicolumn{2}{|c|}{ High income countries } \\
\hline & No. obs & $\begin{array}{c}\text { Mean/Pro } \\
\text { portion }\end{array}$ & No. obs. & Mean & No. obs. & Mean & No. obs. & Mean \\
\hline $\begin{array}{l}\text { Salary as a } \\
\text { proportion of } \\
\text { current salary } \\
\text { if had stayed } \\
\text { in home } \\
\text { country }\end{array}$ & 45 & $0.41^{25}$ & 16 & 0.24 & 22 & 0.44 & 14 & 0.81 \\
\hline Higher & 56 & 0.09 & 23 & 0.00 & 24 & 0.00 & 22 & 0.18 \\
\hline Lower & 56 & 0.79 & 23 & 0.95 & 24 & 0.79 & 22 & 0.64 \\
\hline $\begin{array}{l}\text { Salary as a } \\
\text { proportion of } \\
\text { salary in the } \\
\text { same grade in } \\
\text { home country }\end{array}$ & 47 & 0.31 & 14 & 0.28 & 19 & 0.35 & 13 & 0.80 \\
\hline Higher & 53 & 0.00 & 21 & 0.00 & 23 & 0.00 & 20 & 0.25 \\
\hline Lower & 53 & 0.89 & 21 & 0.95 & 23 & 0.91 & 20 & 0.65 \\
\hline
\end{tabular}

Table 6. Relative salaries for sample doctors.

25 This figure does not include two outliers who claimed that their salary in India would be ten times higher than in the UK. With the outliers the figure would be 0.81 . 


\begin{tabular}{|l|c|c|}
\hline \multicolumn{3}{|l|}{ Reason for coming to the UK for training } \\
\hline India & No. Obs. & Mean \\
\hline Advancing career & 58 & 0.88 \\
Financial advantages & 58 & 0.55 \\
Departmental connection & 58 & 0.19 \\
Personal & 58 & 0.40 \\
Other & 58 & 0.21 \\
\hline Low income & & \\
\hline Advancing career & 28 & 0.89 \\
Financial advantages & 28 & 0.35 \\
Departmental connection & 28 & 0.07 \\
Personal & 28 & 0.57 \\
Other & 28 & 0.14 \\
\hline Middle income & & \\
\hline Advancing career & 28 & 0.86 \\
Financial advantages & 28 & 0.43 \\
Departmental connection & 28 & 0.12 \\
Personal & 28 & 0.39 \\
Other & 28 & 0.29 \\
\hline High income & 23 & \\
\hline Advancing career & 23 & 0.74 \\
Financial advantages & 23 & 0.17 \\
Departmental connection & & 0.17 \\
Personal & 23 & 0.61 \\
Other & & 0.43 \\
\hline
\end{tabular}

Table 7. Summary of respondents' reasons for coming to the UK for training 


\begin{tabular}{|l|c|c|}
\hline India & No. Obs & Mean \\
\hline $\begin{array}{l}\text { Experienced unemployment in the UK } \\
\text { Experienced unemployment in home } \\
\text { country }\end{array}$ & 58 & 0.31 \\
Reduction in grade in the UK & 58 & 0.19 \\
\hline Low income & & 0.63 \\
\hline $\begin{array}{l}\text { Experienced unemployment in the UK } \\
\text { Experienced unemployment in home }\end{array}$ & 27 & 0.30 \\
country & 27 & 0.04 \\
Reduction in grade in the UK & 28 & 0.39 \\
\hline Middle income & & \\
\hline $\begin{array}{l}\text { Experienced unemployment in the UK } \\
\text { Experienced unemployment in home } \\
\text { country }\end{array}$ & 28 & 0.18 \\
Reduction in grade in the UK & 28 & 0.00 \\
\hline High Income & & 0.25 \\
\hline $\begin{array}{l}\text { Experienced unemployment in the UK } \\
\text { Experienced unemployment in home } \\
\text { country }\end{array}$ & 23 & 0.22 \\
Reduction in grade in the UK & 23 & 0.09 \\
\hline
\end{tabular}

Table 8. Unemployment and changes in grade. 


\begin{tabular}{|c|c|c|c|c|c|c|c|c|}
\hline & \multicolumn{2}{|c|}{ India } & \multicolumn{2}{|c|}{ Low income } & \multicolumn{2}{|c|}{ Middle income } & \multicolumn{2}{|c|}{ High income } \\
\hline Reasons for returning & Obs & Mean & Obs & Mean & Mean & Mean & Obs & Mean \\
\hline Family reasons & 26 & 0.81 & 14 & 0.79 & 12 & 0.83 & 4 & 0.25 \\
\hline $\begin{array}{l}\text { Duty to serve the home } \\
\text { country }\end{array}$ & 26 & 0.77 & 14 & 0.71 & 12 & 0.75 & 4 & 0.00 \\
\hline $\begin{array}{l}\text { Lack of opportunities in } \\
\text { the UK }\end{array}$ & 26 & 0.50 & 13 & 0.15 & 12 & 0.08 & 4 & 0.25 \\
\hline Visa/res. Permit & 26 & 0.31 & 13 & 0.23 & 12 & 0.17 & 4 & 0.00 \\
\hline $\begin{array}{l}\text { Do not want to settle in } \\
\text { the UK }\end{array}$ & 26 & 0.62 & 14 & 0.86 & 12 & 0.58 & 4 & 0.50 \\
\hline $\begin{array}{l}\text { Career prospects at } \\
\text { home }\end{array}$ & 25 & 0.32 & 14 & 0.57 & 12 & 0.25 & 4 & 0.00 \\
\hline $\begin{array}{l}\text { Better connections at } \\
\text { home }\end{array}$ & 26 & 0.50 & 14 & 0.79 & 12 & 0.42 & 4 & 0.50 \\
\hline Other & 26 & 0.46 & 14 & 0.36 & 12 & 0.42 & 4 & 0.75 \\
\hline
\end{tabular}

\begin{tabular}{|c|c|c|c|c|c|c|c|c|}
\hline \multirow[b]{2}{*}{$\begin{array}{l}\text { Reason for not } \\
\text { returning }\end{array}$} & \multicolumn{2}{|c|}{ India } & \multicolumn{2}{|c|}{ Low income } & \multicolumn{2}{|c|}{ Middle income } & \multicolumn{2}{|c|}{ High income } \\
\hline & $\mathrm{Ob}$ & Mean & Obs & Mean & Obs & Mean & Obs & Mean \\
\hline $\begin{array}{l}\text { Want to gain more } \\
\text { experience }\end{array}$ & 12 & 0.50 & 5 & 0.40 & 6 & 0.50 & 12 & 0.50 \\
\hline $\begin{array}{l}\text { Better working } \\
\text { conditions }\end{array}$ & 12 & 0.75 & 5 & 0.80 & 6 & 0.83 & 12 & 0.42 \\
\hline Better facilities & 12 & 0.67 & 5 & 0.80 & 6 & 0.83 & 12 & 0.25 \\
\hline UK health care system & 12 & 0.42 & 5 & 0.80 & 6 & 0.67 & 12 & 0.42 \\
\hline $\begin{array}{l}\text { Better relationships with } \\
\text { peers/managers }\end{array}$ & 12 & 0.50 & 5 & 0.40 & 6 & 0.50 & 12 & 0.58 \\
\hline $\begin{array}{l}\text { Better relationships with } \\
\text { juniors }\end{array}$ & 12 & 0.42 & 5 & 0.40 & 6 & 0.50 & 12 & 0.67 \\
\hline Family & 12 & 0.75 & 6 & 0.83 & 6 & 0.83 & 12 & 0.92 \\
\hline Standard of living & 12 & 0.67 & 5 & 0.60 & 6 & 0.83 & 12 & 0.17 \\
\hline Other & 12 & 0.33 & 5 & 0.80 & 6 & 0.17 & 12 & 0.17 \\
\hline
\end{tabular}

Table 9. Summary of reported reasons to return to home country 


\begin{tabular}{|c|c|c|c|c|c|}
\hline & \multicolumn{4}{|c|}{ How difficult to find applicants in general } & \\
\hline $\begin{array}{c}\text { How } \\
\text { difficult to } \\
\text { Replace }\end{array}$ & Very Easy & Easy & Difficult & $\begin{array}{c}\text { Very } \\
\text { Difficult }\end{array}$ & Total \\
\hline Very Easy & 8 & 8 & 1 & 0 & 17 \\
\hline Easy & 2 & 36 & 7 & 0 & 45 \\
\hline Difficult & 0 & 8 & 10 & 1 & 19 \\
\hline Very & 0 & 1 & 3 & 3 & 7 \\
Difficult & & & & & 88 \\
\hline Total & 10 & 53 & 21 & 4 & \\
\hline
\end{tabular}
$\chi^{2}$ for symmetry
6.67
Proportion test $\mathrm{p}=0.36$
Degrees of freedom
5

Table 10. Respondents' assessments of employers' difficulties of replacing them and general difficulty to find applicants in their home country

\begin{tabular}{|c|c|c|c|c|c|}
\hline & \multicolumn{4}{|c|}{ How difficult to find a post in general } & \\
\hline $\begin{array}{c}\text { How difficult } \\
\text { to find a post } \\
\text { (personally) }\end{array}$ & $\begin{array}{c}\text { Very } \\
\text { Easy }\end{array}$ & Easy & Difficult & $\begin{array}{c}\text { Very } \\
\text { Difficult }\end{array}$ & Total \\
\hline Very Easy & 2 & 7 & 5 & 2 & 16 \\
\hline Easy & 2 & 22 & 22 & 7 & 53 \\
\hline Difficult & 1 & 2 & 22 & 8 & 33 \\
\hline Very & 0 & 3 & 10 & 14 & 27 \\
Difficult & & & & & 129 \\
\hline Total & 5 & 33 & 59 & 31 & \\
\hline
\end{tabular}
$\chi^{2}$ for symmetry
25.93
Proportional test $\mathrm{p}=0.000097$
Degrees of freedom
6

Table 11. Respondents' assessments of the difficulty of finding a post in the UK 


\begin{tabular}{|c|c|c|c|c|c|}
\hline & \multicolumn{3}{|c|}{ How difficult to find a placement (in general) } & \\
\hline $\begin{array}{c}\text { How difficult } \\
\text { to find a } \\
\text { placement } \\
\text { (personally) }\end{array}$ & Very Easy & Easy & Difficult & $\begin{array}{c}\text { Very } \\
\text { Difficult }\end{array}$ & Total \\
\hline Very Easy & 1 & 2 & 0 & 0 & 3 \\
\hline Easy & 0 & 3 & 8 & 2 & 13 \\
\hline Difficult & 0 & 3 & 9 & 2 & 14 \\
\hline Very Difficult & 0 & 0 & 0 & 4 & 4 \\
\hline Total & 1 & 8 & 17 & 8 & 33 \\
\hline
\end{tabular}
$\chi^{2}$ for symmetry
8.27273
Proportion test $\quad \mathrm{p}=0.006$
Degrees of freedom
4

Table 12. Respondents' assessments of difficulty of finding a placement

\begin{tabular}{|c|c|c|c|c|c|}
\hline & \multicolumn{5}{|c|}{ Level of facilities before coming to the UK } \\
\hline $\begin{array}{c}\text { Difficulty to find a } \\
\text { decent medical } \\
\text { training post }\end{array}$ & $\begin{array}{c}\text { Completely } \\
\text { inadequate }\end{array}$ & Inadequate & Good & Very good & Total \\
\hline Very Easy & 2 & 0 & 2 & 2 & 6 \\
\hline Easy & 0 & 7 & 16 & 12 & 35 \\
\hline Difficult & 0 & 8 & 27 & 6 & 41 \\
\hline Very Difficult & 1 & 5 & 10 & 4 & 20 \\
\hline Total & 3 & 20 & 55 & 24 & 102 \\
\hline
\end{tabular}

Chi squared

28.34

Degrees of freedom

9

Table 13. Assessments of difficulty to find a decent medical training post and level of facilities before coming to the UK 


\begin{tabular}{|c|c|c|c|c|c|c|c|c|}
\hline & \multicolumn{2}{|c|}{ India } & \multicolumn{2}{|c|}{ Low income } & \multicolumn{2}{|c|}{ Middle income } & \multicolumn{2}{|c|}{ High Income } \\
\hline \multicolumn{9}{|c|}{ Did the prospect of being able to work abroad affect your decisions } \\
\hline $\begin{array}{l}\text { To study } \\
\text { medicine }\end{array}$ & 58 & 0.09 & 27 & 0.41 & 28 & 0.36 & 23 & 0.52 \\
\hline $\begin{array}{l}\text { Choice of } \\
\text { university }\end{array}$ & 58 & 0.10 & 27 & 0.30 & 28 & 0.21 & 23 & 0.13 \\
\hline $\begin{array}{l}\text { Choice of } \\
\text { specialty }\end{array}$ & 58 & 0.22 & 27 & 0.33 & 28 & 0.14 & 23 & 0.22 \\
\hline $\begin{array}{l}\text { Training } \\
\text { abroad }\end{array}$ & 58 & 0.34 & 27 & 0.37 & 28 & 0.36 & 23 & 0.57 \\
\hline $\begin{array}{l}\text { Financing } \\
\text { education }\end{array}$ & 58 & 0.21 & 27 & 0.11 & 28 & 0.21 & 23 & 0.17 \\
\hline $\begin{array}{l}\text { Effort put } \\
\text { into studies }\end{array}$ & 58 & 0.28 & 27 & 0.37 & 28 & 0.29 & 23 & 0.22 \\
\hline \multicolumn{9}{|c|}{$\begin{array}{l}\text { In your view, does the prospect of working abroad usually affect medical students' or doctors' decisions in } \\
\text { your home country }\end{array}$} \\
\hline $\begin{array}{l}\text { To study } \\
\text { medicine }\end{array}$ & 56 & 0.21 & 26 & 0.46 & 27 & 0.33 & 19 & 0.16 \\
\hline $\begin{array}{l}\text { Choice of } \\
\text { university }\end{array}$ & 56 & 0.23 & 26 & 0.30 & 27 & 0.41 & 19 & 0.11 \\
\hline $\begin{array}{l}\text { Choice of } \\
\text { specialty }\end{array}$ & 56 & 0.43 & 26 & 0.50 & 27 & 0.33 & 19 & 0.26 \\
\hline $\begin{array}{l}\text { Training } \\
\text { abroad }\end{array}$ & 56 & 0.54 & 26 & 0.62 & 27 & 0.63 & 19 & 0.47 \\
\hline $\begin{array}{l}\text { Financing } \\
\text { education }\end{array}$ & 56 & 0.46 & 26 & 0.35 & 27 & 0.48 & 19 & 0.16 \\
\hline $\begin{array}{l}\text { Effort put } \\
\text { into studies }\end{array}$ & 56 & 0.36 & 26 & 0.46 & 27 & 0.41 & 19 & 0.26 \\
\hline
\end{tabular}

Table 14. The influence of the possibility of migration on respondents' decisions.

\begin{tabular}{|c|c|c|c|c|c|}
\hline & \multicolumn{4}{|c|}{ How difficult to find a decent training post } \\
\cline { 2 - 6 } & Very easy & Easy & Difficult & Very difficult & Total \\
\hline $\begin{array}{c}\text { The possibility of migration } \\
\text { did not have effect }\end{array}$ & 1 & 23 & 20 & 6 & 50 \\
\hline $\begin{array}{c}\text { The possibility of migration } \\
\text { had an effect }\end{array}$ & 6 & 24 & 29 & 21 & 80 \\
\hline Total & 7 & 47 & 49 & 27 & 130 \\
\hline
\end{tabular}

$\begin{array}{ll}\text { Chi squared } & 7.03 \\ \text { Degrees of freedom } & 3\end{array}$

Table 15. The effect of migration on decisions and assessments of difficulty of finding a decent training post. 


\begin{tabular}{|c|c|c|c|c|c|c|c|c|}
\hline & \multicolumn{2}{|c|}{ India } & \multicolumn{2}{|c|}{ Low income countries } & \multicolumn{2}{|c|}{$\begin{array}{c}\begin{array}{c}\text { Middle income } \\
\text { countries }\end{array} \\
\end{array}$} & \multicolumn{2}{|c|}{ High income countries } \\
\hline & No. obs & Mean & No. obs & Mean & No. obs & Mean & No. obs & Mean \\
\hline Free & 57 & 0.70 & 28 & 0.57 & 28 & 0.39 & 23 & 0.74 \\
\hline Scholarship & 57 & 0.23 & 28 & 0.14 & 28 & 0.39 & 23 & 0.04 \\
\hline Grant & 57 & 0.04 & 28 & 0.14 & 28 & 0.07 & 23 & 0.04 \\
\hline Gift & 57 & 0.02 & 28 & 0.07 & 28 & 0.04 & 23 & 0.00 \\
\hline $\begin{array}{l}\text { Corporate } \\
\text { sponsor }\end{array}$ & 57 & 0.02 & 28 & 0.00 & 28 & 0.04 & 23 & 0.00 \\
\hline $\begin{array}{l}\text { Private } \\
\text { means }\end{array}$ & 57 & 0.82 & 28 & 0.75 & 28 & 0.68 & 23 & 0.78 \\
\hline Borrowing & 57 & 0.12 & 28 & 0.04 & 28 & 0.29 & 23 & 0.22 \\
\hline
\end{tabular}

Table 16. Sources of funding for education

\begin{tabular}{|l|c|c|c|c|c|c|c|c|}
\hline & \multicolumn{2}{|c|}{ Low income } & \multicolumn{2}{c|}{ Middle income } & \multicolumn{2}{|c|}{ High income } & \multicolumn{2}{c|}{ India } \\
\hline $\begin{array}{l}\text { Support spouse } \\
\text { and children } \\
\begin{array}{l}\text { Support other } \\
\text { relatives }\end{array}\end{array} \quad 12$ & 0.08 & 13 & 0.00 & 7 & 0.00 & 30 & 0.03 \\
Pay off debts & 12 & 0.83 & 13 & 0.38 & 7 & 0.14 & 30 & 0.73 \\
Investments & 12 & 0.00 & 13 & 0.31 & 7 & 0.00 & 30 & 0.23 \\
Saving & 12 & 0.17 & 13 & 0.23 & 7 & 0.14 & 30 & 0.23 \\
Other & 12 & 0.25 & 13 & 0.31 & 7 & 0.71 & 30 & 0.47 \\
\end{tabular}

Table 17. Motives to send remittances by country group. 
Figure 1: Mountford-the possibility of migration raises expected returns to education.

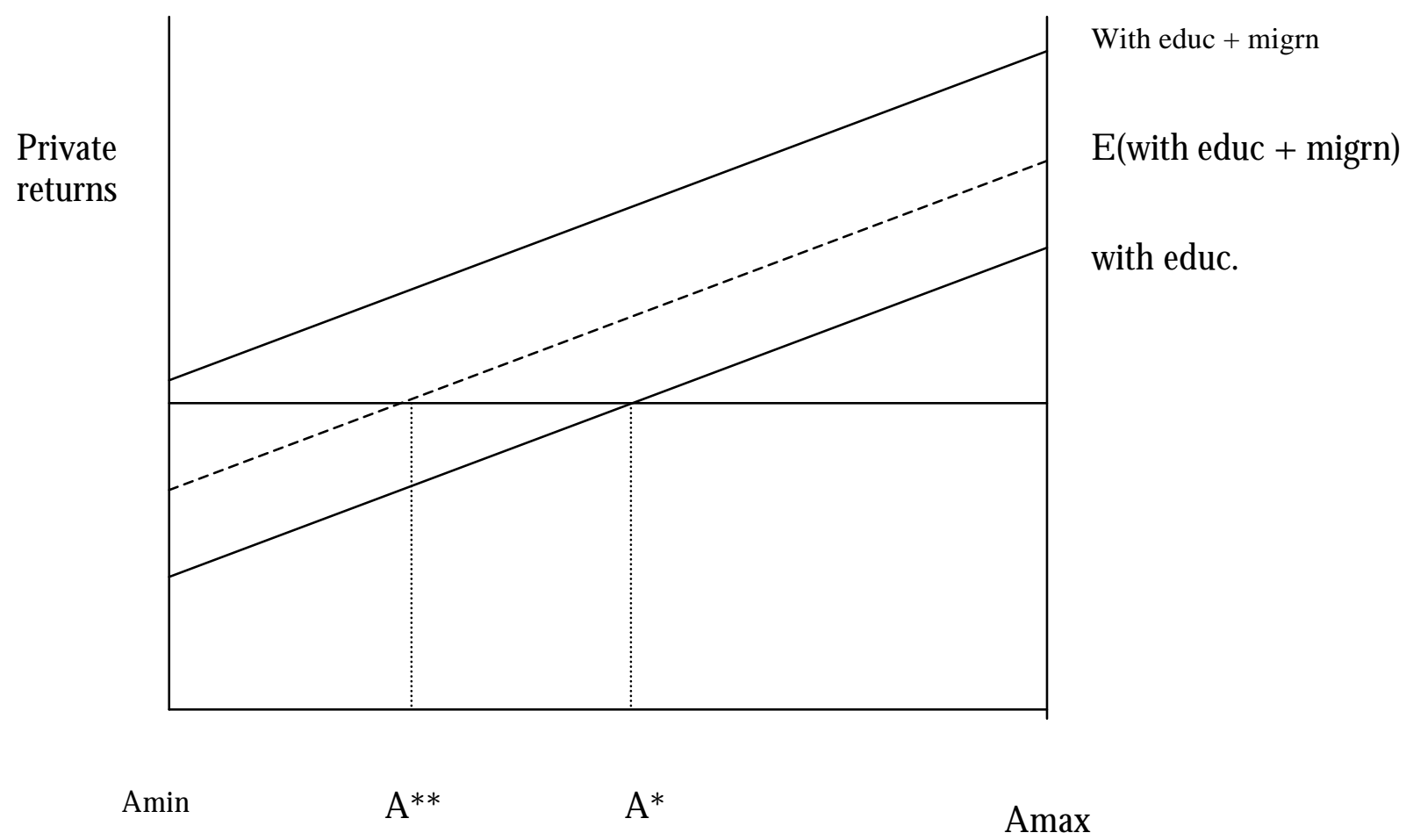

Figure 2: Mountford with perfect screening: the incentives for the marginal student do not change because they will never be chosen for migration.

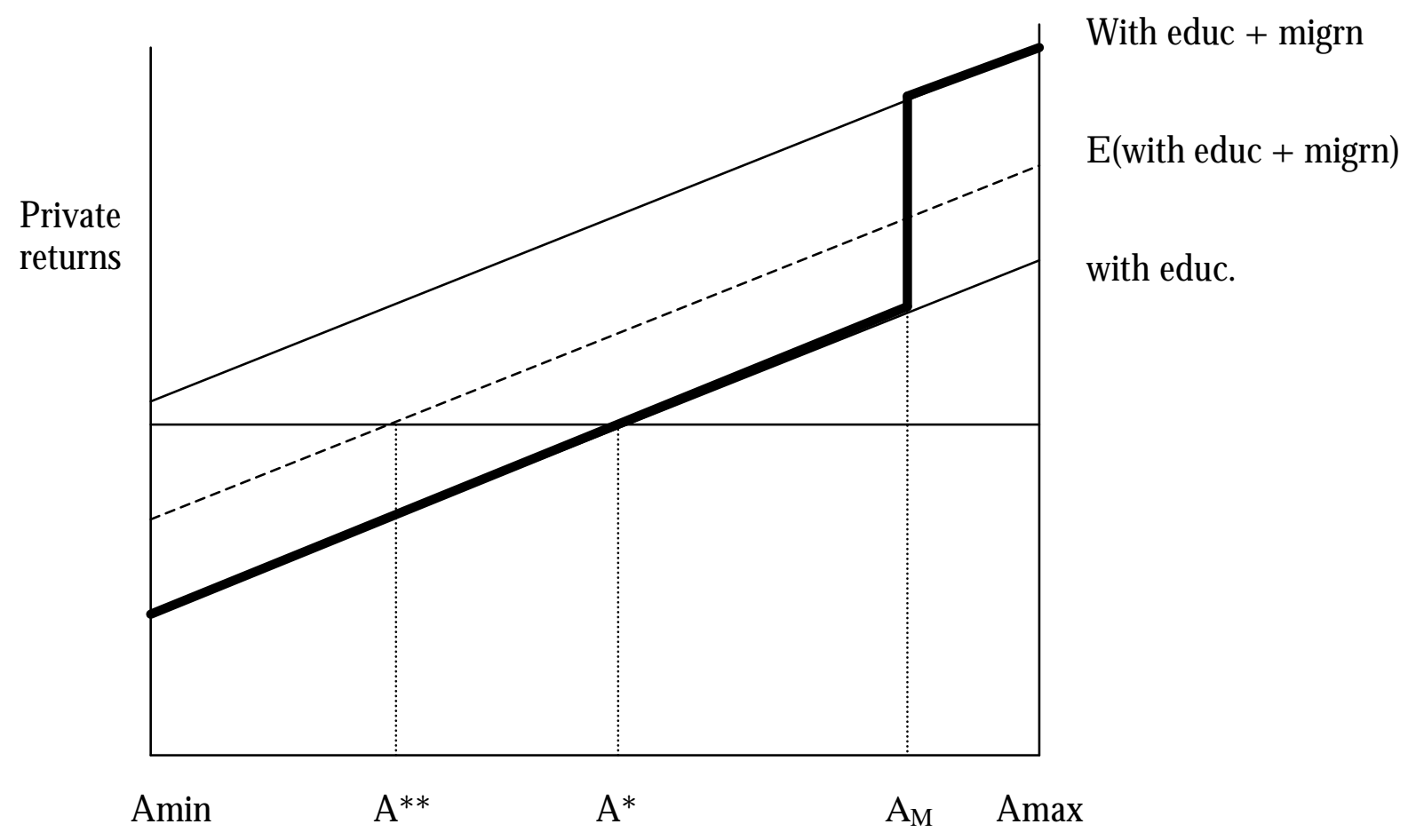




\section{Appendix}

A questionnaire for telephone survey of doctors in the United Kingdom

\section{Introduction}

Hello, I'm calling from the University of Sussex .My name is You participated a study by the Open University and kindly volunteered to participate another survey by a sister project. The aim of this survey is to study the reasons and implications of migration of doctors. Would you have 20 minutes to answer some questions? You can refuse to answer any of the questions if you wish. All your answers will naturally be anonymous and treated with confidentiality. The data will be eventually used for academic research.

1. What is your country of origin?

<If asked to clarify: country of birth.>

<If UK, do not continue.>

Thank you for your time, good bye. etc.

<If overseas, proceed.>

\section{Part 1 Personal details}

2. Gender

3. Age

4. Marital status: Married/Single

<If married ask questions 5 and 6. > <If single, go to 7.>

5. Is you spouse from the UK or overseas? UK/Overseas

6. Does you spouse live in the UK? Yes/No

7. Do you have dependants (children)? Yes/No

8. What is your GMC registration status? Provisional/Limited/Full

9. What is your current visa status?

Settled status/ indefinite residence

Training and work experience certificate (TWES)

Work pemit

Pemit free status

Unknown

10. Do you have refugee status? Yes/No 


\section{Part 2 Professional background}

11. What was your first medical degree

12. Institution and the year of obtaining the first medical degree

13. Class or grade of the degree, converted into the following categories:

\section{Excellent}

Good

Average

Degree not graded

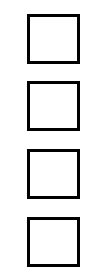

$<$ In the following questions "home country" means primarily the country of origin, and this should be mentioned. However, if the respondent considers some other non-UK country as his or her home, make a note on this and ensure that in the future questions "home country" is understood consistently referring to this country.>

14. Describe briefly your work history in different countries (the number of years of professional experience, including postgraduate training, and when it took place) since obtaining the first medical degree:

Home country

UK

Other countries

$<$ If any in the home country questions $15-18>$

<If none in the home country, go to question 19>

15. How many of those in your home country in the private sector?

16. Was your last post in your home country in public or private sector?

\section{Public sector}

\section{Private sector}

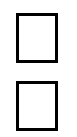

17. Was it located in rural or urban areas?

\section{Rural}

Unban

18. What type of institution was it? 


\section{Hospital \\ Health care centre/ Surgery}

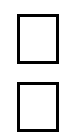

19. Reason for going abroad for further training, please tick all those that apply:

A. To obtain reputable training and advance career thereafter

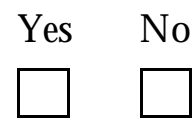

B. Financial advantages or higher standard of living

C. Departmental connections/ sponsorship/ specific placements

D. Personal reasons

E. Other

(specify)
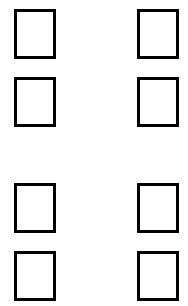

20. What was your grade prior to entry to the UK (as UK equivalent) and in which country was that?

\section{PRH O $\square \quad$ SHO $\square \quad$ SpR $\square \quad$ Consultant $\square$ Other (specify)}

21. How good were the facilities (equipment, supporting staff etc.) provided in the last post you held in that grade prior to coming to the UK?

\section{Very good}

Good

Inadequate

Completely inadequate

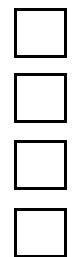

22. How difficult is it to get a decent medical training post in your home country with your qualifications?

Very difficult

Difficult

Easy

Very easy

23. Where was your first training post? 
24. How long did it take for you to find your first post after obtaining your degree?

Less than a month

1-2 months

3-6 months

More than 6 months

25. What was your employment situation when you left for the UK?

\section{Working (including postgraduate training) in home country}

Unemployed

Not working for some other reason, or working elsewhere

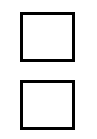

<If employed, question 26.> <If not employed, go to question 27.>

26. In your view, how difficult was it for your last employer in your home country to find equally qualified applicant to replace you?

Very difficult

Difficult

Easy

Very easy

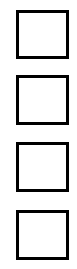

27. In your view, how difficult in general is it for employers to find suitably quatified doctors in your home country?

Very difficult

Difficult

Easy

Very easy

28. What is you current grade in the UK?
Locum

Clinical

Attachment
SHO

Trust D octor
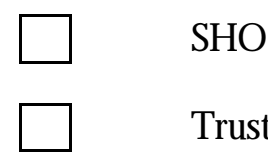

Associate Specialist

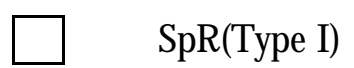

Staff Grade

Other (specify)
SpR(Type II)

Clinical Fellow

29. What year did you take up your current grade (in the $\mathrm{UK})$ ? 
30. Was your first clinical experience in the UK in this grade? Yes/No

<If no, questions 31 and 32.> <If yes, go to question 33.>

31. What was your first clinical experience in the UK?

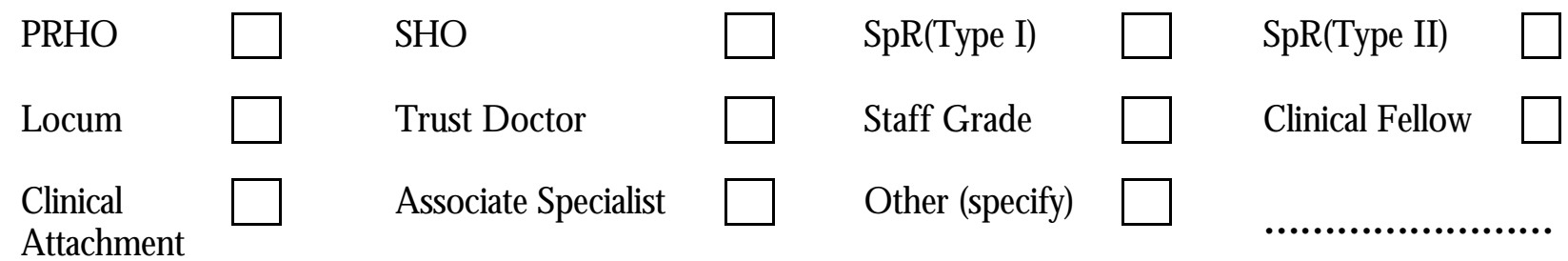

32. What year did you take up your first post in the UK?

33. Have you experienced spells of involuntary unemployment as a qualified doctor in th UK? Yes/No

34. Have you experienced spells of involuntary unemployment as a qualified doctor in your home country? Yes/No

35. What was your route to entry to the UK?

PLAB

Direct Placement

ODTS

EEA member

PLAB exempt

(med. D egree

recognised)

Other (specify)

<If EEA, PLAB exe mpt or other, go to question 39.>

$<$ If direct placement or ODTS, questions $37 \& 38$.>

<If PLAB, question 36.> 
36. How many times did you attempt PLAB test before passing it? (Note: if there is different number of attempts in part I and part II, use the higher number)

Only once

Twice

Three times

More than three times

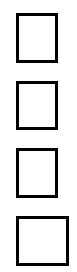

<Go to question 39.>

37. How difficult did you find it to obtain a direct placement or place in the overseas doctors' training scheme?

\section{Very difficult}

Difficult

Easy

Very easy

38. In your view, how difficult is it to obtain a placement or place in the overseas doctors' training scheme for doctors from your country in general?

Very difficult

Difficult

Easy

Very easy

39. Have you ever applied for a post through normal routes (i.e. by sending applications directly to the hospitals/surgeries) in the UK? Yes/No

<If yes, questions 40, 41 and 42.> <If no, go to 43.>

40. How difficult did you find it to find a post in the UK?

\section{Very difficult}

Difficult

Easy

Very easy

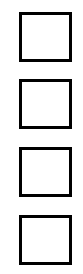


41. When applying for your last post, approximately how many applications did you send?

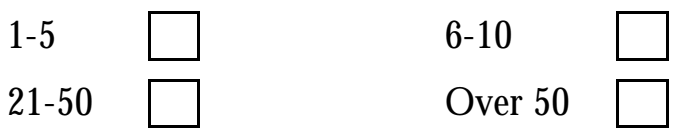

$11-20$

$21-50$

Over 50

42. In your view, how difficult is finding a post (outside ODTS or a direct placement scheme) in the UK for doctors from your country in general?

Very difficult

Difficult

Easy

Very easy

\section{Part 3 Educational decisions/finance}

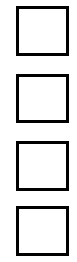

43. Did the prospect of being able to work abroad affect your decisions (please tick all those that apply):

A. To train in medicine at all

B. On which college/ university to apply to

C. On which speciality to adopt

D. On whether to seek training abroad

E. On how to finance your training

F. On how much effort to put into achieving good grades in your medical studies

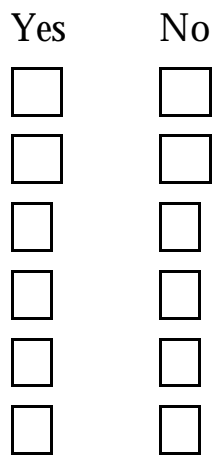

44. In your view, does the prospect of working abroad usually affect medical students' or doctors' decisions in your home country:

A. To train in medicine at all

B. On which college/ university to apply to

C. On which speciality to adopt

D. On whether to seek training abroad

E. On how to finance your training

F. On how much effort to put into achieving good grades in their medical studies

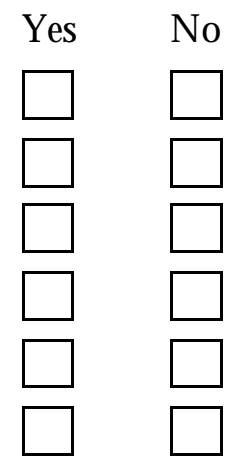


45. How did you finance your medical studies (tick any substantial contributions over one quarter of total cost)? (Total cost refers to tuition fees and living costs.)

A. Public provision of training (basically free at point of delivery, also including training where work is required in retum)

B. Competitive scholarship (please specify from which

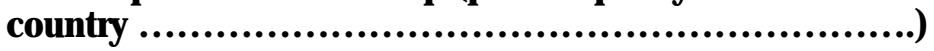

C. Public student grants or benefits (please specify from which country............................. .

D. Gift/ Personal sponsors

E. Corporate sponsorship

F. Private means (incl. parents and own savings)

G. Bomowing

46. Did/does your postgraduate training in the UK involve any direct costs to you? Yes/No

<If yes, question 47.> <If no, go to 48.>

47. How are you financing or did finance the personal, direct costs of your postgraduate training in the UK (tick any substantial contributions over one quarter of total cost)?
A. Competitive scholarship
B. Gift/ Personal sponsors
C. Comporate sponsorship
D. Private means
E. Bormowing

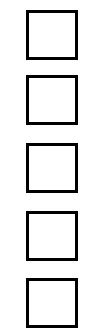

48. To your knowledge, does some other body or organisation pay some of the costs of training on your behalf? Yes/No

$<$ If yes, 49> <If no, go to 50.>

49. Which organisation? 
50. In the light of your experience in the UK, do you think you should have made different decisions about:
A. On whether to train medicine at all with the plan to go abroad
Yes No
B. On whether to seek training in the UK
C. On where in the UK to seek a post
D. On which speciality to adopt
E. On how to finance your training

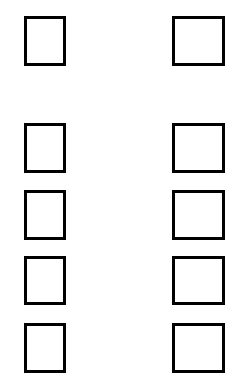

\section{Part 4 Salary and remittances}

51. What would be your annual salary in your home country now, if you had continued work ing there until now, compared to your current salary?

52. What is the approximate salary in your current grade in your home country, compared to your current salary?

53. Do you send remittances to your home country? Yes/No

$<$ If any remittances, questions $54 \& 55><$ If no, go to 56.>

54. How much do you send to your home country as remittances, compared to your current salary?

55. What is the purpose of these remittances? Please tick all that apply.

A Contribute to living costs of spouse and children

B. Contribute to living costs of other relatives

C. Pay off debts

D. Investments to generate returns

E. Saving for the future use

F. Other, please specify

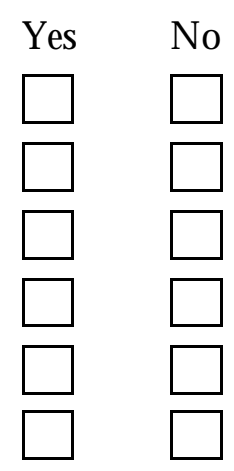




\section{Part 5 Future plans}

56. Do you intend to:
A. Retum to your home country
Yes
No
Don't know
B. Emigrate to a third country
Yes, specify.........
No
Don't know

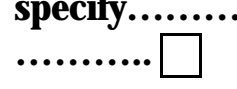

<If don't know to A, go to question 63>

$<$ If no to A, go to question 61>

$<$ If yes to A, questions 57, 58 and 59>

57. If you intend to return to your home country when will you return:
A. In 1-2 years
B. In 3-4 years
C. In 5-6 years
D. In 7-10 years
E. In 10+ years

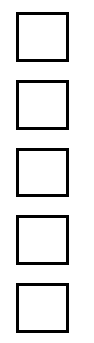

58. What will be the main reasons for your return? Please tick all that apply.
A. Because of family reasons
B. Because of duty to serve the home country
C. Lack of job opportunities in the UK
D. D ifficulties to get a visa or a residence pemit
E. Because you do not want to settle in the UK
F. Better career opportunities at home
G. Better connections and networks at home
H. Other

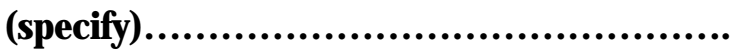

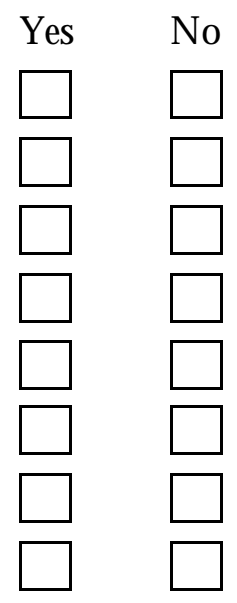


58. Where are you most likely to work in your home country immediately after your return?

Public sector

Private sector

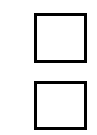

Rural

Unban

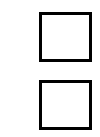

Hospital

Health care centre/ Surgery

59. Are you likely to still work in this type of institution five (5) years after your return? Yes/No

$<$ If yes, go to question 63.>

$<$ If no, question 60.>

60. Where are you most likely to work 5 years after your return?

Public sector

Private sector

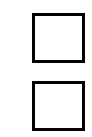

Rural

Unban

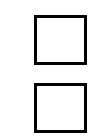

Hospital

Health care centre/ Surgery

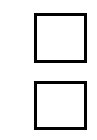


61. Which of the following reasons have influenced your decision not to go back to your

home country? (Please tick all those that apply.)

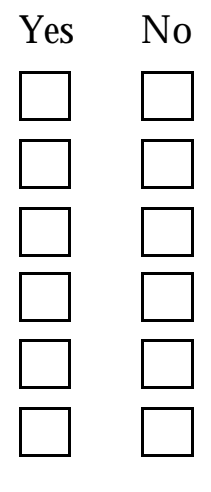
professionals
G. For family/ personal reasons
H. An improved standard of living
I. 0 ther (specify)

62. Under what conditions (in your home country) would you decide to return? Please tick all that apply.
A. Better facilities or working conditions
B. Higher salary, at least...
.per annum
C. Different organisation of health care
D. Different working relationships
E. Under no conditions
F. Other (specify)

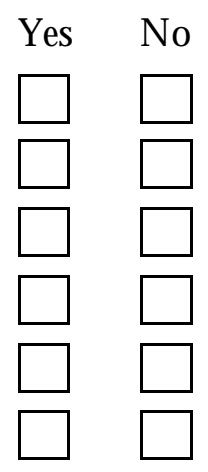

63. When you first came to the UK, did you intend to stay after your training? Please tick all that apply.

Yes

No

Don't know

$<$ if Yes/No and respondent does not know whether to return home or emigrate to a third country, or if don't know in 63, finish>

$<$ If yes and respondent also currently intends to stay, finish>

$<$ If no and respondent also currently intends to return or move to a third country, finish>

$<$ If yes in question 63, but respondent currently intends to return or move to a third country, question 65>

$<$ If no, but respondent currently has no intention to return or move to a third country, go to question 64> 
64. If you did not intend to stay, but have changed your mind, why? Please tick all that apply.
A. Facilities and working conditions are better than expected.
B. Standard of living is higher than expected.
C. Cultural differences are smaller than expected.
D. Work experience in the UK seems more useful than expected.

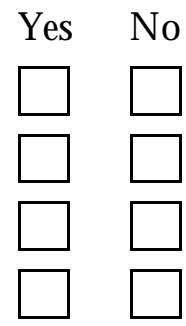
E. Career prospects are better than expected.
F. Other (please specify)

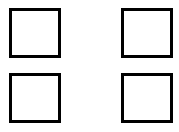

<Finish.>

65. If you intended to stay, but now intend to leave, why? Please tick all that app.
A. Facilities and working conditions are worse than expected.
B. Standard of living is lower than expected.
C. Cultural differences are larger than expected.
D. Expenience in the UK is not likely to be as useful as expected.

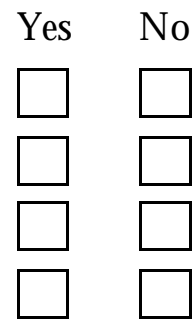
E. Career prospects in the UK are worse than expected.
F. Other (please specify)

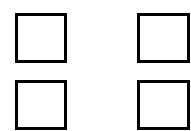

<Finish.> 


\section{Appendix 2}

\section{Results of probit and ordered probit estimations}

Ordered probit for grade attained before coming to the UK (Indian doctors)

No. obs. 49

\section{Explanatory variable}

Experience before coming to the UK

Top university

Female

Age

Excellent degree

Years of experience in private sector
Coeff.

0.225

$-0.115$

0.735

$-0.015$

$-0.343$

$-0.097$

$\begin{array}{cc}\text { Std.error } & \mathbf{p} \\ 0.069 & 0.001 \\ 0.427 & 0.788 \\ 0.426 & 0.085 \\ 0.039 & 0.701 \\ 0.395 & 0.386 \\ 0.142 & 0.497\end{array}$

No. obs. 55

\section{Probit for choosing ODTS (Indian doctors)}

\section{Explanatory variable}

Grade before entry: SpR

Grade before entry: consultant

Grade before entry: other

Top university

Excellent degree

Entry cohort

Experience before coming to the

UK, years

Constant
Coeff.

2.344

3.013

2.822

0.522

0.794

0.023

$-0.054$

$-2.760$
Std. Error

0.760

0.994

1.237

0.631

0.530

0.055

0.059

1.329
0.001

0.085

0.701

0.497

No. obs. 105

\section{Ordered probit for the level of facilities}

\section{Variable}

Middle income country

High income country

India

Easy to find a decent medical

training post

Difficult to find a decent medical

training post

Very difficult to find a decent

medical training post

Easy to find qualified applicants

Difficult to find qualified applicants

Very difficult to find qualified

applicants

$\begin{array}{ccc}\text { coefficient } & \text { std dev } & \mathbf{p} \\ -0.418 & 0.366 & 0.253 \\ 1.181 & 0.441 & 0.007 \\ 0.430 & 0.316 & 0.174 \\ 0.575 & 0.434 & 0.185 \\ & & \\ 0.052 & 0.426 & 0.902 \\ & & \\ -0.236 & 0.467 & 0.614 \\ 0.141 & 0.310 & 0.650 \\ 0.285 & 0.342 & 0.404 \\ 0.304 & 0.643 & 0.636\end{array}$




\section{References}

Beecham, Linda, 2002, 'UK government should stop recruiting doctors from abroad'. BMJ 2002; 325: pp. 66.

Beine M, Docquier F and Rapoport H, 2001a, 'Brain drain and economic growth: theory and evidence,' Journal of Development Economics, v64, n1 (February) pp. 275-89.

Beine M, Docquier F and Rapoport H, 2001b, 'Brain drain and growth in LDCs: winners and losers', Paper presented at European Economic Association Congress, August.

Bhagwati, Jagdish N., Hamada, Koichi, 1974, 'The Brain Drain, International Integration of Markets for Professionals and Unemployment: A Theoretical Analysis', Journal of Development Economics v1, n1 (June), pp.19-42.

Bundred, Peter E and Levitt, Cheryl, 2000, 'Medical migration: who are the real losers?'. The Lancet 2000; 356: pp. 245-46.

Carrington, William J. \& Detragiache, Enrica, 1998, 'How Big is the Brain Drain?', IMF Working paper no. 201.

Constable, Joanne, Fish, Isabel and McKenna, Claire, 2002, 'A quick guide to working in the United Kingdom'. BMJ 2002;325;S153.

Simon Commander, Mari Kangasniemi and L. Alan Winters: 'The Brain Drain: Curse or Boon? A Survey of the Literature.' Discussion paper no. 809, IZA.

Davis, Margery, 2000, 'Prospective Comparative Study of the Progress of Overseas Medical Graduates'. Manuscript.

Findlay, A M, Li, F L N, Jowett, A J, Brown M and Skeldon, R, 1994, 'Doctors diagnose their destination: an analysis of the length of employment abroad for Hong Kong doctors'. Environment and Planning A, vol. 26, pp. 1605-1624.

Goldfarb, Robert, Havrylyshyn, Oli and Magnum, Stephen, 1984, 'Can Remittances Compensate for Manpower Outflows: The Case of Philippine Physicians'. Journal of Development Economics, 15, pp. 1-17.

Grubel, H. and Scott, A., 1966, 'The International Flow of Human Capital', American Economic Review, Vol. 56, No. 1/2. (Mar., 1966), pp. 268-274.

Gupta, Romes and Lingam, Sundara, 1999, 'The overseas doctors training scheme'. BMJ $1999 ; 318$.

Hamada, Koichi ; Bhagwati, Jagdish N., 1975, 'Domestic Distortions, Imperfect Information and the Brain Drain', Journal of Development Economics v2, n3 (September), pp. 265-79. 
Jayaram, N., 1995, 'Political Economy of Medical Education in India', Higher Education Policy, v8, n2.

Johnson, H. G., 1967, 'Some economic aspects of the brain drain', Pakistani Development Review, 7, pp. 379-411.

Mountford, A, 1997, 'Can a brain drain be good for growth in the source economy?', Journal of Development Economics v53, n2 (August), pp. 287-303.

Rivett, Geoffrey, 1997, From Cradle to Grave: Fifty Years of the NHS. King's Fund, London.

Rodriguez, C.A., 1975, 'Brain Drain and Economic Growth: A dynamic model.' Journal of Development Economics v2, n3 (September), pp. 223-248.

Sridhar, M K, 1998, 'UK encourages unrealistic expectations among overseas applicants for training'. BMJ 1998;316: pp. 473-474.

Sridhar, Mangalam, 2000, 'What is the future for training overseas graduates?'. BMJ 2000;321: p. 307.

Stark, O, Helmenstein C and Prskawetz A, 1997, 'A brain gain with a brain drain', Economics Letters, v55, n3 (July), 227-34.

Stark, O, Helmenstein C and Prskawetz A, 1998, 'Human capital depletion, human capital formation, and migration: a blessing or a curse?', Economics Letters, v60, n3 (September), pp. 363-67.

Vidal, J-P, 1998, 'The effect of emigration on human capital formation,' Journal of Population Economics, v11, n4 (December), pp. 589-600.

Welsh, Christopher, 2000, 'Training overseas doctors in the United Kingdom'. BMJ 200;321; pp. 253-254.

Wickens, Thomas D., 1989, Multiway Contingency Tables Analysis for the Social Sciences. Lawrence Erlbaum Associates, Hillsdale, New Jersey. 


\section{CENTRE FOR ECONOMIC PERFORMANCE \\ Recent Discussion Papers}

617 Vicentre CuZat

Maria Guadalupe

616 James Harrigan

Anthony J. Venables

615 Howard Gospel

Paul Willman

614 Andrew B. Bernard

Stephen Redding

Peter K. Schott

Helen Simpson

613 David Marsden

612 David G. Blanchflower Alex Bryson

611 Stephen Gibbons

Stephen Machin

610 Johannes Hörner

L.Rachel Ngai

Claudia Olivetti

609 Nikolaus Wolf

608 Ellen E. Meade

David Stasavage

607 Ghazala Azmat

Maia Güell

Alan Manning

606 Henry G. Overman

L. Alan Winters
Executive Compensation and Product Market

Competition

Timelines, Trade and Agglomeration

Comparatively Open: Statutory Information Disclosure for Consultation and Bargaining in Germany, France and the UK

Relative Wage Variation and Industry Location

Unions and Procedural Justice: An Alternative to the Common Rule

The Union Wage Premium in the US and the UK

Valuing Rail Access Using Transport Innovation

Public Enterprises and Labor Market Performance

Endowments, Market Potential, and Industrial Location: Evidence from Interwar Poland (1918-1939)

Publicity of Debate and the Incentive to Dissent:

Evidence from the US Federal Reserve

Gender Gaps in Unemployment Rates in OECD

Countries

The Geography of UK International Trade 
605 Stephen Machin

Stephen Wood

604 Maarten Goos

Alan Manning

603 Nan-Kuang Chen

Hsiao-Lei Chu

602 Ricardo Peccei

Helen Bewley

Howard Gospel

Paul Willman

601 Andy Charlwood

600 Christopher A. Pissarides

599 Stephen Bond

Dietmar Harhoff

John Van Reenen

598 Michael Storper

Anthony J. Venables

597 Stephen Gibbons

Alan Manning

596 Paul Gregg

Maria Gutiérrez-

Domènech

Jane Waldfogel

595 Stephen Bond

Dietmar Harhoff

John Van Reenen
Looking for HRM/Union Substitution: Evidence from British Workplaces

Lousy and Lovely Jobs: the Rising Polarization of Work in Britain

Collateral Value and Forbearance Lending

Is it Good To Talk? Information Disclosure and Organisational Performance in the UK

Incorporating evidence submitted on the DTI discussion paper 'High Performance Workplaces Informing and Consulting Employees'

The Anatomy of Union Decline in Britain 1990-1998

Unemployment in Britain: A European Success Story

Corporate R\&D and Productivity in Germany and the United Kingdom

Buzz: Face-to-Face Contact and the Urban Economy

The Incidence of UK Housing Benefit: Evidence from the 1990s Reforms

The Employment of Married Mothers in Great

Britain: 1974-2000

Investment, R\&D and Financial Constraints in Britain and Germany 